\title{
Review \\ Oligodendrocytes and Microglia: Key Players in Myelin Development, Damage and Repair
}

\author{
Ilias Kalafatakis ${ }^{1,2}$ and Domna Karagogeos ${ }^{1,2, *}$ \\ 1 Laboratory of Neuroscience, Department of Basic Science, University of Crete Medical School, \\ 70013 Heraklion, Greece; ilias_kalafatakis@imbb.forth.gr \\ 2 IMBB FORTH, Nikolaou Plastira 100, Vassilika Vouton, 70013 Heraklion, Greece \\ * Correspondence: karagoge@imbb.forth.gr; Tel.: +30-281-039-4542
}

Citation: Kalafatakis, I.;

Karagogeos, D. Oligodendrocytes and Microglia: Key Players in Myelin Development, Damage and Repair. Biomolecules 2021, 11, 1058 . https://doi.org/10.3390/ biom 11071058

Academic Editor:

Vasileia Ismini Alexaki

Received: 30 May 2021

Accepted: 16 July 2021

Published: 20 July 2021

Publisher's Note: MDPI stays neutral with regard to jurisdictional claims in published maps and institutional affiliations.

\begin{abstract}
Oligodendrocytes, the myelin-making cells of the CNS, regulate the complex process of myelination under physiological and pathological conditions, significantly aided by other glial cell types such as microglia, the brain-resident, macrophage-like innate immune cells. In this review, we summarize how oligodendrocytes orchestrate myelination, and especially myelin repair after damage, and present novel aspects of oligodendroglial functions. We emphasize the contribution of microglia in the generation and regeneration of myelin by discussing their beneficial and detrimental roles, especially in remyelination, underlining the cellular and molecular components involved. Finally, we present recent findings towards human stem cell-derived preclinical models for the study of microglia in human pathologies and on the role of microbiome on glial cell functions.
\end{abstract}

Keywords: oligodendrocytes; microglia; myelin; inflammation; demyelination; remyelination; multiple sclerosis

\section{The Importance of Myelin}

The myelin sheath is the membranous structure that surrounds most of the central (CNS) and peripheral (PNS) nervous system axons of vertebrates. It is an evolutionary adaptation that allows fast signal propagation along bigger distances, a feature of the increasing body size of animals. Myelin is produced by myelinating glial cell, the oligodendrocyte in the CNS and Schwann cell in the PNS, spirally arranged around the axon in a compact sheath. Signal conduction is optimal due to the increase in resistance and decrease in the membrane capacitance of axons, which increase the velocity of action potential propagation up to tenfold [1,2].

In addition to this important insulating function, myelin assumes several critical functions in the nervous system. It protects axons mechanically by isolating the electrical signal from the microenvironment. Importantly, oligodendrocytes have been shown to provide metabolic support to neurons and to regulate ion and water homeostasis [3-6]. It has been appreciated recently that oligodendrocytes influence neuronal circuits by being able to respond to activity-dependent changes by regulating myelin production [7-10]. Indeed, our understanding of the events leading to myelin production has been enriched by recently identified regulatory factors that control different aspects of glial development and by large scale analysis showing a great diversity and complexity of progenitors and mature cells involved in myelination, a process that is seen as active throughout the life of the organism.

The regulation of myelination, either during development or during repair or adaptive conditions, is mediated by complex interactions between neurons and glia. In particular, all types of glial cells participate in not yet completely elucidated ways, in myelin development and its modulation. In this review we discuss essential aspects of the crosstalk between oligodendrocytes and another glial cell type, the microglia, in maintaining 
myelin homeostasis, and also examine how this cross-talk is influenced under conditions of inflammation that often lead to myelin pathologies.

\section{Oligodendrogial Development at a Glance}

Myelinating oligodendrocytes originate from oligodendrocyte precursor cells (OPCs) which are highly proliferative cells derived in discrete waves during development. In the forebrain ventricular zone, for example, neuroepithelial progenitors generate OPCs from E12.5 until birth. OPCs are characterized by the expression of platelet-derived growth factor receptor A (PDGFR-a), the neuron-glial antigen 2 (NG2) proteoglycan and gangliosides recognized by the A2B5 antibody. Elegant studies on oligodendroglial development have elucidated the mechanisms of specification and differentiation of OPCs to the myelinating phenotype and have shown that Shh-dependent (early phase) and independent (late phase) signaling, as well as expression of the transcription factors Olig1, Olig2, Mash, Nkx2.2 and Sox10, are essential in these processes. OPCs migrate while still proliferating to populate the CNS, differentiate to a premyelinating identity, and at this point are able to wrap around axons; however, they are still unable to form mature myelin, a step that occurs upon expression of myelic basic protein (MBP) and myelin oligodendrocyte glycoprotein (MOG). Several key regulators of this journey have been identified, including morphogen signaling (Shh, Wnt) as well as several transcription factors and miRNAs [11-13].

As myelin keeps being generated in the healthy adult CNS, at least two sources of OPCs have been revealed, namely the progenitors of the subventricular zone (SVZ) and the NG2+/PDGFR $\alpha+$ cells distributed throughout the CNS. These cells maintain their proliferative ability so that oligodendrocytes are generated continuously. Recent data points to the formation of new oligodendrocytes as an important process in myelin plasticity coupled to the learning of motor skills [14,15].

\section{Myelin Damage}

Demyelination is defined as myelin loss around axons, either due to congenital conditions or a CNS insult (such as inflammation or injury). The prototype of demyelinating pathological entity is multiple sclerosis (MS), a chronic, inflammatory disease causing focal destruction of the myelin sheath and a glial scar. MS is the most common acquired demyelinating CNS disease with yet unknown etiology. In brain magnetic resonance imaging (MRI) the pathological hallmark of the disease manifests itself as white matter plaques that are hyperintense lesions widely scattered throughout the CNS, although the optic nerves, brainstem, spinal cord and periventricular white matter are the sites usually affected. The pathogenesis of MS is characterized by disruption of the blood-brain barrier with subsequent active immune cell recruitment and a cascade of pathologies that range from infiltration of lymphocytes and activation of microglia to the destruction of the myelin sheath and the degeneration of axons [16-18].

In MS, a cascade of neuroinflammatory processes finally leads to the injury of myelinating oligodendrocytes causing demyelination; although the initial insult leading to oligodendrocyte death and myelin loss remains elusive, these events could arise from infiltrating immune cells but also within the CNS itself [19].

It is generally accepted that a prophagocytic activity precedes full-blown myelin phagocytosis. These early events do not show evidence of oligodendrocyte apoptosis, pointing to alternative mechanisms of cell death. Microglia are observed in these early-stage lesions. Myelin phagocytosis is considered to arise by the action of myelin-specific T cells that have been activated by antigen-presenting cells (microglia and dendritic cells) and thus start the full inflammatory sequence of events. In the previously resting inflammatory cascade, parenchymal microglia also participate by releasing cytokines such as interleukin 12 (IL-12) and IL-13, which enhance Th1 cell differentiation and myelin damage through the release of $\mathrm{NO}$ and glutamate. Using an inducible model of adult oligodendrocyte depletion, it was shown that oligodendrocyte loss is followed by CD4+ T cells leading to a secondary demyelination [20]. Although some of the pathophysiological mechanisms and players responsible for CNS demyelination have been described [21], the full picture still 
needs to be elucidated. Thus, it is unclear whether oligodendrocyte injury is the root or the outcome of inflammation.

Several models of demyelination in rodents exist. Not a single one is able to recapitulate all aspects of human disease, but the most common models resemble distinct phases and stages of the condition (inflammatory, autoimmune and demyelination-remyelination processes). In these models, demyelination is brought about through immune system stimulation, local or systemic toxin introduction, genetically-encoded toxin expression or viral transduction. The experimental autoimmune encephalomyelitis (EAE), the toxic cuprizone demyelination model and the lysolecithin (LPC) model are among the most commonly used [22,23].

\section{Myelin Repair}

Myelin repair occurs in the human CNS as well as in some rodent models of MS. Remyelinated axons have a characteristically thin myelin sheath and short internodes. However, extensive heterogeneity exists due to disease duration, stage and phenotype. It is unclear at the moment whether indeed, as some studies show, remyelination is more efficient in early demyelinating lesions and then follows a diminishing course [24,25]. It has been observed that the demyelinating disease progression superimposes and takes over myelin repair, indicating a close interplay between the two processes [26] suggesting myelin repair is not restricted to early phases of demyelinating pathology.

Why then, is repair after CNS insult not sustained, as evidenced by the majority of MS lesions being of the chronic demyelinating type [27]? The reasons for remyelination failure are not well understood [28]. It was shown that axons do not become properly remyelinated due to the formation of a glial scar $[29,30]$. Periventricular lesions seem to be more affected than deep white matter or cortical lesions. A number of factors have been described as possible underlying reasons for limited myelin repair over the course of disease; among them, OPC numbers may be decreased [31,32]. In MS, as well as in mouse models, OPC recruitment and differentiation to mature myelinating oligodendrocytes is negatively affected $[33,34]$. OPCs gradually lose their remyelinating ability and need to be activated so that they can become responsive to factors enhancing their mobilization to the injured area and proceeding to differentiate to the myelinating phenotype [35-39]. OPC differentiation and recruitment is negatively impacted by an unfavorable microenvironment due to increased expression of Notch and Wnt signaling, as well as modulation of expression of chemorepellent Semaphorin 3A and chemoattractant Semaphorin 3F [34,40,41]. Another factor that negatively affects remyelination is aging. Aging leads to changes of the microenvironment that negatively affect OPC recruitment and differentiation during demyelinating conditions [42].

Animal models resembling stages of MS, as well as studies on postmortem human tissue, show that adult progenitors with OPC characteristics, as well as neural stem cells expressing glial fibrillary acidic protein (GFAP) and Nestin at the SVZ, are able to remyelinate denuded axons [43-46]. In general, myelin repair is the outcome of complex interactions between all glial types, not just oligodendrocytes, as is detailed in the following sections. However, the oligodendrocytes are essential players and, as described below, their functions extend well beyond myelin formation.

\section{Oligodendrocytes: More than Just Forming Myelin}

Recently, the intriguing idea that OPCs may be harnessed by the immune system under demyelination conditions to perpetuate the autoimmune response has been put forward $[47,48]$. OPCs and oligodendrocytes in both human and murine settings are able to act as antigen-presenting cells and activate CD8+ T cells. A subset of oligodendroglial cells express genes involved in antigen processing and presentation and have an inflammatory signature as assessed by single cell RNAseq, are therefore named iOPC/iOLs. These studies reveal an intermediary oligodendrocyte phenotype in humans, while in the mouse both OPC and OL upregulate antigen-presenting molecules $[47,49,50]$. Therefore, these cells have the potential to be in direct communication with CD8+ T cells. Although 
many aspects of this novel activity of oligodendroglial cells need to be investigated, experiments using $\mathrm{T}$ cells recognizing foreign peptides, and transgenic lines with cell-type specific expression of the foreign peptides, suggest that antigen presentation by $\mathrm{iOPC} / \mathrm{iOL}$ is effective after T cells have already been primed by dendritic cells. What is interesting, in addition, is the possibility the iOPLC/iOL may be able to modulate aspects of OL survival and differentiation.

One more active area of research regarding the oligodendrocyte microenvironment has been the investigation of exosomes (extracellular vesicles, EVs) in the light of their function as mediators of cross-talk between various cellular players, including oligodendrocytes and microglia [51-57]. Originally recognized as a mechanism of discarding unwanted cellular material, EVs are also important signaling intermediaries. EVs released by oligodendrocytes may represent a significant vehicle of communication during development and upon injury. Neuronal signals trigger OL-EVs which, in turn, are taken up by neurons or microglia in their microenvironment [51,53-55]. In particular, microglia pick up OL-EVs via micropinocytosis, and subsequently process the contents though the endolysosomal compartment and thus maintain the homeostatic turnover of myelin components. OL-EVs may also mediate neuroprotection by providing support to neurons upon demand. Similar studies in pathological contexts may be helpful in elucidating the role of OL-EVs in disease. An autocrine model of OL-EV mode of action has been suggested to operate in inhibiting myelin formation in vitro [58]. In this context, it was recently shown that EVs released from activated microglia block remyelination, a process mediated directly by astrocytes, while EVs released from anti-inflammatory microglia promoted remyelination in a lysolecithin-induced demyelinating lesion ([59] and relevant section below).

\section{Microglia: Origins and Homeostatic Functions}

Microglia comprise $10 \%$ of total glial cells and represent the myeloid resident population of the CNS [60]. Microglia originate from yolk-sac macrophages (YSM) entering the brain after the first generation of neurons [61], while expanding and self-renewing during adulthood [62]. Apart from their immune roles, recent studies have shown that both fetal and adult microglia contribute to diverse processes including synaptic transmission, synaptic pruning and formation, cell death and survival, as well as brain wiring $[62,63]$.

In the 100 years since they were first established as a distinct CNS population, research on this versatile cell type has revolutionized the field of neuroinflammation [64]. Microglia have been traditionally described as the macrophages of the CNS, able to scavenge dying cells, pathogens and molecules, as well as myelin debris in pathological conditions, but more recently they have been recognized as much more than typical scavengers. They are characterized by a continuum of activation states. Microglia are the brain-resident, macrophage-like, innate immune cells that are able to respond with the necessary flexibility in a context-specific nature. Under homeostatic conditions, microglia exhibit a ramified morphology, and their role is to "scan" the CNS for potential insults. In general, microglia are able to switch between pro and anti-inflammatory states in order to maintain tissue homeostasis in response to the environment, and are able to interact with neurons, astrocytes and oligodendrocytes contingent on their particular function [65]. A recent study focused on the analysis of the RNA expression patterns of more than 76,000 individual microglia in mice during development, in old age, and after brain injury. The results showed at least nine transcriptionally distinct microglial states, which expressed unique sets of genes and were localized in the brain using specific markers. The highest heterogeneity was found at young ages, although several chemokine-enriched inflammatory microglia persisted even in the aged brain. Multiple reactive microglial subtypes were also found following demyelination in mice. These results can be used for the better understanding of microglia function and for the identification and manipulation of specific microglia subpopulations in health and disease [66]. 


\section{Role of Microglia in Myelin Development}

During development, microglia play essential roles in the establishment of neuronal numbers as well as shaping neuronal circuits by clearing dead cells and by pruning or remodeling synapses, and, in general, modulating emerging neuronal wiring [67-74]. In addition to this important array of functions, microglia also support OPCs and OLs. The developing white matter contains microglial clusters which are thought to be involved in myelin formation $[75,76]$. One possible way microglia can be involved in developmental myelination is by secreting trophic factors for which OPCs, generated in excess, compete [77]. During development, activated microglia of the SVZ secrete TNF $\alpha$, IL-1 $\beta$, IL-6 and IFN- $\gamma$, and promote oligodendrocyte development. When the levels of these cytokines are reduced, oligodendrogenesis is impaired [78]. Early work on microglia-oligodendrocyte cocultures indicated that microglia activate oligodendrocytes to synthesize the myelinspecific galactolipid sulfatide in addition to myelin proteins MBP and PLP [79].

A series of in vitro studies have supported multiple mechanisms of microglia beneficial roles on OPC survival and maturation [80-82]. Microglia-conditioned medium rescues OPCs from cell death due to growth factor withdrawal and promotes their differentiation [83]. Similar media enhance OPC chemotaxis and proliferation. IL-2 and IL-10 activation of microglia enhances survival and differentiation of OPCs [84]. IL-4 activation of microglia drives neural precursors towards the oligodendroglial lineage [85]. In vivo studies of a knockout of CSFIR, a gene encoding a tyrosine kinase receptor required in macrophages, showed a significant depletion of microglia, perturbed brain development and a severe decrease in mature oligodendrocytes in particular areas of the CNS [86,87]. As transcriptome analysis of CNS region-specific microglia suggests, microglia populations in distinct brain areas may be more or less supportive of oligodendroglial development [88]. Single cell profiling studies have revealed a great degree of regional heterogeneity of microglial populations with the cerebellar one having a unique profile [89-91]. An example of a unique population of microglia that mainly appears in primary myelinating areas of the developing brain is the $\mathrm{CD} 11 \mathrm{c}+$ microglial subset that expresses genes for neuronal and glial survival, migration and differentiation. CD11c+ microglia have an amoeboid morphology and localize close to white matter tracts (corpus callosum and cerebellum). They are present early during embryonic development, while their numbers peak between P3 and P7. Upregulation of 39 genes is associated with developmental CD11c+ microglia, revealing a common signature for this specific cell type. These cells constitute the major source of insulin-like growth factor 1 (IGF-1), while their selective depletion leads to impairment of primary myelination [76].

As mentioned above, microglia phagocytose neurons and synapses during development. A recent study revealed that they also phagocytose excess myelin sheaths, a process regulated by neuronal activity and called myelin pruning [92]. Another study showed that a specific population of microglia migrate from the ventricular zone into the corpus callosum during development, phagocytosing viable OPCs before the onset of myelination. Mice lacking the fractalkine receptor exhibit a reduction in microglial engulfment of viable OPCs, increased numbers of oligodendrocytes and reduced myelin thickness, indicating that microglia phagocytose OPCs as a homeostatic mechanism leading to proper myelination. Impairment of microglial pruning of OPCs could lead to hypomyelinating developmental disorders or adult demyelinating diseases [93].

In the adult, contrary to their active role in development, microglia have been considered rather inactive. However, in vivo imaging studies have revealed that microglial cells actively survey their surroundings [94,95] and interact with their neighbors [96]. Factors regulating microglia morphology in adult brain homeostasis include purinoreceptors, ion channels and neurotransmitters $[97,98]$. Microglia clearing of cell debris does not require them to be in an activated (amoeboid) state. 


\section{Role of Microglia in Demyelinating Disorders}

In the past few years it has become evident that microglia are active determinants of neurodegenerative diseases, among them Alzheimer's, Huntington's, Parkinson's disease and MS [64]. This review focuses on the involvement of microglia in MS and, in particular, the interactions of microglia and oligodendrocytes either in the context of MS or in animal models resembling aspects of MS. In these pathological conditions, microglia are shown to release both pro and anti-inflammatory soluble factors, and present self-antigens to immune cells.

During CNS injury, microglia are activated, changing to an amoeboid morphology. When microglia are activated they can either promote inflammation and cytotoxicity by secreting factors such as IL-1, IL-12, IL-23, tumor necrosis factor alpha (TNFa) and inducible nitric oxidase synthase (iNOS) or reduce inflammation and promote neuroprotection by secreting factors such as IL-4, IL-10, IL-13, transforming growth factor beta (TGF $\beta$ ) and arginase 1 (Arg-1) [87,99,100].

Microglia are involved in both the de and remyelination phase of MS [101]. During demyelination, microglia undergo phagocytosis of myelin debris and secrete proinflammatory molecules [102-105]. Postmortem analysis of lesions in MS patients shows a high number of immature oligodendrocytes in acute, active lesions, which are characterized by a robust inflammatory response suggesting that extensive oligodendrocyte regeneration occurs in some plaques early in the course of the disease [106]. It is thus considered that the inflammatory environment during demyelination may stimulate the process of remyelination, starting with the myelin debris clearance by microglia [107-110]. Following injury, different inflammatory factors are secreted by microglia in the surrounding milieu such as IL-12, IL-13, NO, TNF $\alpha$ and glutamate. The net result is antigen-presenting activity and cytokine/chemokine release on the part of microglia propagating inflammation within the CNS. Intriguingly, this microglial activation and accumulation within the damaged area of the neuronal parenchyma plays both beneficial and detrimental roles during myelin damage and repair.

\section{Beneficial Roles of Microglia}

It has been demonstrated beyond doubt that neuroinflammation promotes neurogenesis and facilitates axonal regeneration and remyelination. In this section we focus on molecular pathways that may be operating in microglial cells, with particular emphasis on remyelination (Figure 1).
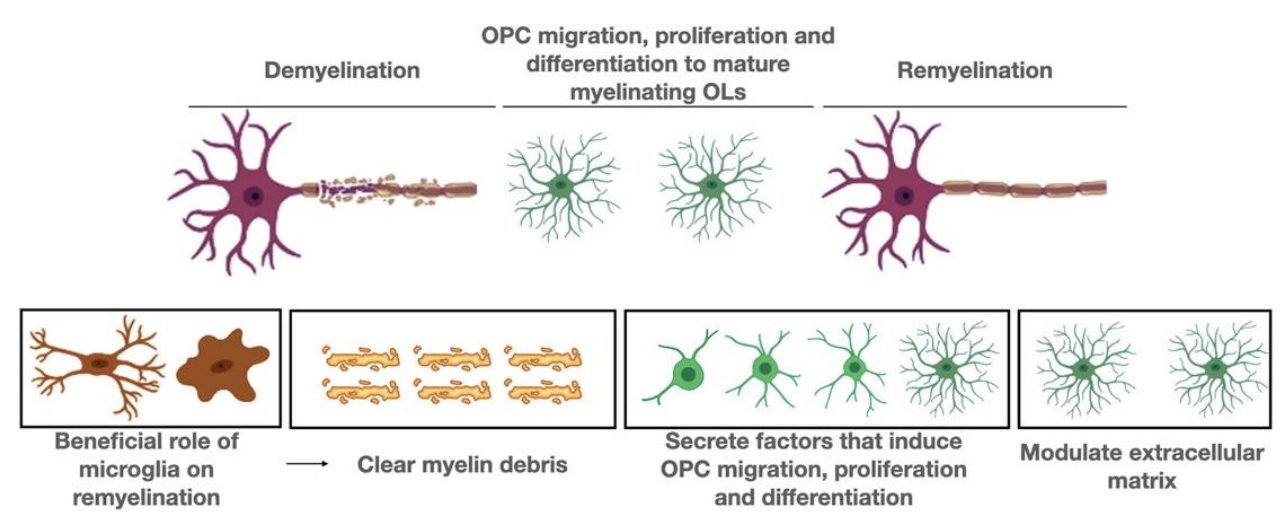

Figure 1. Beneficial role of microglia on remyelination. Microglia promote remyelination in three ways. First, they remove myelin debris, a procedure that is essential for the initiation of remyelination. Second, they secrete factors that promote OPC migration, proliferation and differentiation into mature myelinating oligodendrocytes. Third, they modify the extracellular matrix.

Conditioned medium from nonactivated microglia increased OPC survival and differentiation by upregulating the PDGFR $\alpha$-signaling pathway accompanied by NF- kB activation [80]. The iron status of microglia also affects OL survival, as iron is a cofactor for enzymatic activity in CNS cells and OLs, which are demanding in energy needs and partic- 
ularly sensitive to iron dysregulation. Conditioned medium from iron-loaded microglia increased survival of OL cultures via the release of $\mathrm{H}$-ferritin, although iron-loaded LPSactivated microglia had the reverse effect [111]. Insulin growth factor 2 (IGF-2), present in conditioned media from nonactivated and activated microglia also promoted OPC survival and differentiation [80].

In vitro studies show that microglia-conditioned medium accelerated OL differentiation in a more efficient manner than conditioned-medium from astrocyte cultures. Analysis of the media revealed a distinct composition in the two types of media. Astrocyteconditioned medium contained higher quantities of platelet-derived growth factor alpha (PDGF $\alpha$ ), fibroblast growth factor 2 (FGF2), FGF2-binding protein, ciliary neurotrophic factor (CNTF), growth hormone (GH), TIMP metallopeptidase inhibitor 1 (TIMP-1) and thrombospondin (THBS1). In contrast, in microglia-conditioned medium, levels of IGF-1, E-selectin (CD62E), fractalkine (CX3CL1), neuropilin-2 (NRP-2), IL-2, IL-5 and vascular endothelial growth factor (VEGF) were significantly increased. This differential composition of cytokines and growth factors in the conditioned media of astrocytes and microglia reflects the distinct intracellular signaling pathways that are activated in OPCs upon exposure to the two different media [83].

Another chemokine that is expressed by microglia and influences the OL lineage is CXCL-1. It reduces OPC migration during development, while it protects OLs from apoptosis during viral-induced demyelination [112,113]. Additionally, CXCL-1 overexpression reduces the severity of EAE [114].

During remyelination, microglia can play both beneficial and detrimental roles. $\mathrm{Mi}-$ croglia in early remyelinating lesions in MS patients are characterized by a predominant expression of the chemokine receptor CCR5, indicating that microglia may play a role in the initiation of remyelination [115]. A change in microglia polarization from an activation to a repair profile can initiate remyelination [84]. In this seminal work, in vitro, ex vivo and in vivo data indicate that M2 microglia (the anti-inflammatory type) drive OL differentiation and remyelination. As remyelination starts, a switch from M1 (proinflammatory) microglia phenotype to an anti-inflammatory phenotype is evident. M2 depletion inhibits OL differentiation in vivo, and increased M2 numbers are seen during efficient remyelination. Oligodendrocyte differentiation is enhanced with M2 microglia-conditioned medium in vitro and impaired with M1-conditioned medium. Furthermore, the authors showed that activin-A in the M2-derived media is able to drive OL differentiation in ex vivo cerebellar organotypic slices [84].

A well-established aspect of microglia during remyelination concerns their fundamental role in the clearance of myelin debris. Myelin debris has to be removed from the injury site in order for the remyelination process to be effective [116]. In the cuprizone-induced model of demyelination, myelin debris clearance by microglia depends on the presence of the microglial triggering receptor expressed on myeloid cells 2 (TREM2). TREM2 is expressed on the cell surface and binds polyanions, thus activating downstream signaling cascades through the adapter DAP12. Trem2(-/-) microglia fail to amplify transcripts indicative of activation, phagocytosis, and lipid catabolism in response to myelin damage, and thus Trem2(-/-) mice cannot efficiently phagocytose myelin debris, a necessary step to promote remyelination $[87,112]$. In the same toxic demyelination cuprizone model, it was shown that astrocytes recruit microglia to the lesion site to clear damaged myelin, a process which is regulated by the chemokine CXCL-10. Upon depletion of astrocytes and, consequently, microglia, removal of myelin debris is significantly delayed, resulting in the inhibition of OPC proliferation and resulting in decreased remyelination [117]. With age, microglia become less efficient at clearing myelin debris, while they also alter their gene expression profiles. Astrocytes also change during aging and it is possible that these changes have a negative impact on remyelination, although additional studies should be performed [42]. In a recent study it was shown that not only myelin removal by microglia is essential for remyelination, but also myelin proper degradation. Defective metabolism of myelin leads to cholesterol accumulation intracellularly in microglia cells, resulting in 
activation of the inflammasome, increase of the inflammatory reaction and blockage of remyelination [118].

During remyelination, microglia express galectin-3 (Gal-3), an essential factor for OPC differentiation [82,119]. Another molecule that positively affects OLs is osteopontin (OPN). Previous studies showed that OPN, expressed by microglia, both increased OPC proliferation and myelin synthesis in vitro [120]. CXCL-12 (otherwise known as stromal cell-derived facto 1), a factor well studied and shown to be important in OPC migration, is expressed by microglia in MS lesions [121,122]. Microglia surrounding MS lesions are shown to express Semaphorin-3F (SEMA3F), which is able to attract OPCs to damaged areas [123].

A surprising finding regarding the role of TNF- $\alpha$, known to be secreted by activated microglia as a pro-inflammatory cytokine (see also next section), has been described [124]. In the cuprizone mouse model, lacking TNF- $\alpha$ and its associated receptors led to a delay in remyelination. This failure of myelin repair was correlated with reduced OPC progenitors and an associated reduction of mature OLs [124]. Moreover, it was revealed that when TNFR2, but not TNFR1, was missing, regeneration was impaired. Thus, TNF- $\alpha$ has a reparative role other than its more well-known detrimental function. Other signaling molecules that have been shown to be important in vivo in the clearance of myelin debris and remyelination include IL-1 $\beta$ [29] and macrophage colony-stimulating factor (M-CSF), which stimulates survival and differentiation of myeloid cells [87,125]. Finally, Arg-1 is a key factor in the regulation of microglia activation, as this enzyme is expressed by microglia upon internalization of myelin and is correlated with suppression of neuroinflammation [84,126]. In EAE, when Arg-1 expression is enhanced, the progression of the disease is reversed [127]. However, inhibition of Arg-1 may be correlated with impaired immune responses and thus the role of Arg-1 remains unclear [128].

Apparently, both M1 and M2 microglia have a function in remyelination, because in early stage, M1 (pro-inflammatory) phenotypes predominate while at later post demyelination stages the M2 phenotypes are more abundant. When the corresponding types (M1 or M2) are depleted, OPC differentiation is impaired [84,129]. Mononuclear phagocytes, including microglia, play an important role in both tissue damage and repair in neuroinflammatory conditions such as MS. A recent study introduced an in vivo imaging approach that allowed the temporal and spatial investigation of the evolution of phagocyte polarization in a murine model of MS. In this study it was shown that individual phagocytes shift their phenotype in response to CNS-derived signals. These findings suggest that the initial proinflammatory polarization of phagocytes, including microglia, needs to be prevented rather than reversed. Moreover, the timing of interventions aiming to block phagocyte infiltration or activation is crucial. While these interventions are possibly beneficial during lesion formation, they could have opposing effects during lesion resolution [130].

Human MS brain studies corroborate the idea that microglia contribute in a beneficial manner to the process of remyelination. The density of microglia correlates with the density of OPCs and, in addition, a higher density of microglia at the lesion borders of plaques correlates with higher remyelination propensity [131,132].

Many of the studies on microglial activation have been performed by incubating the cells with lipopolysaccharide (LPS). In these studies, microglia promote OPC and OL survival through IGF-1 and the PI3/Akt pathway as well as the mitochondrial apoptotic pathway due to suppression of caspase activity [133]. However, in vivo treatment with IGF-1 in a rodent EAE model failed to provide conclusive evidence of its efficacy $[134,135]$. In vitro LPS treatment with microglia showed an increase in the levels of expression of neurotrophins, supporting the idea that proinflammatory microglia are able to express neuroprotective molecules [136]. In particular the role of BDNF has been studied in detail and shown that by producing it, microglia impair antigenic presentation and promote not only neuronal but also OL survival/differentiation in rodent de and remyelination models such as the cuprizone model [137-142]. 


\section{Detrimental Roles of Microglia}

As discussed above, the view that proinflammatory microglia have damaging effects on neurogenesis or gliogenesis is outdated. Evidence has been mounting that inflammation not only aims at clearing debris but also at promoting tissue regeneration. However, there are several detrimental effects of microglia that we discuss below (Figure 2).

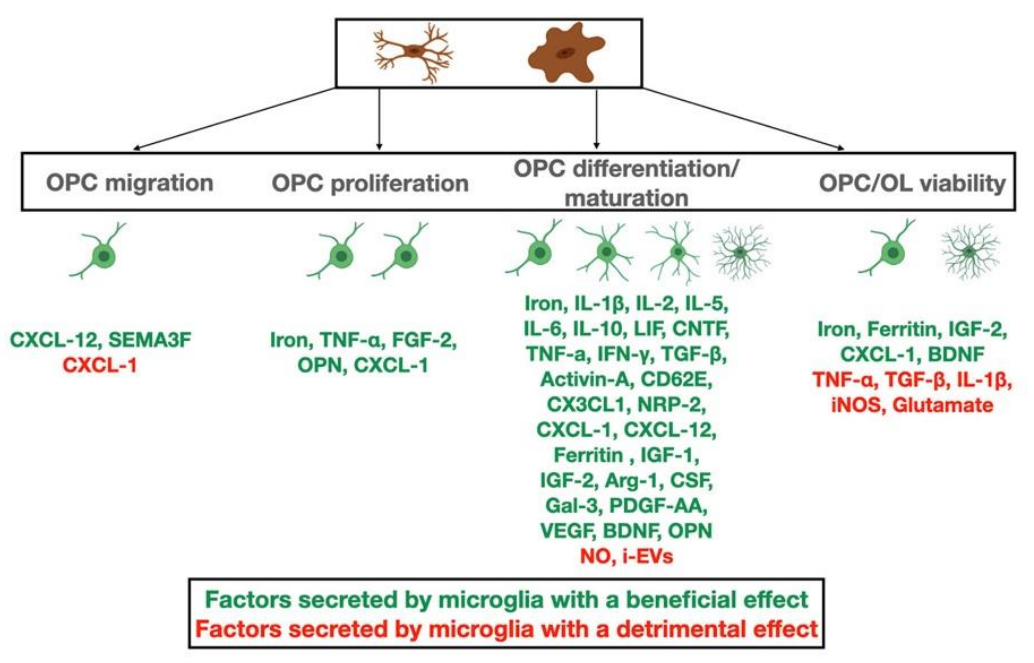

Figure 2. Inflammatory factors secreted by microglia during demyelination and remyelination that affect OPC migration, proliferation and differentiation to mature myelinating OLs, as well as OPC/OL survival. Factors with beneficial effects are listed with green color, while factors with detrimental effects are listed with red color.

Microglia are able to exert antigen presenting functions on myelin-specific $\mathrm{T}$ cells infiltrating the CNS, thus initiating inflammation. As a result, resting microglia start secreting Th1-promoting cytokines IL-12 and IL-13. Th1 cells, in turn, release a number of agents toxic to myelin, including NO and glutamate $[143,144]$. If these microglia are selectively eliminated, EAE symptoms become less severe and myelin loss is reduced, while blockade of CD40, which is involved in the activation process, also reduces EAE severity $[145,146]$. Activated microglia secrete $\mathrm{TNF} \alpha$, a strong proinflammatory cytokine; when this release is blocked EAE symptoms are ameliorated [147]. TAK1, a MAP3K, TGF- $\beta$ activated kinase, when inactivated, specifically in microglia, suppress EAE symptoms, via NF-KB, JNK and ERK1/2 pathways. Thus, these pathways seem to be essential for the CNS inflammation and accompanying myelin and axonal damage, mediated by microglia [148].

When microglial cells are stimulated in vitro with LPS, cytotoxic effectors are released and damaging effects on OPCs and OLs are exerted. OPC differentiation is impeded by NOdependent oxidative damage early on, and by TNF $\alpha$ later on [149]. When astrocytes are present, LPS-activated microglia become toxic to differentiating oligodendrocytes via TNF signaling, but not via NO-dependent oxidative damage [150]. When microglia are polarized by CD137 (a member of the tumor necrosis factor receptor family), OL apoptosis is promoted [151].

The harmful effects of microglia on oligodendrocytes may be mediated through astrocytes due to the release of IL-1 $\alpha$, TNF and C1q [152-155]. A recent report shows that, in an LPC-model in vivo, EVs released by activated, proinflammatory microglia (i-EVs) block remyelination by blocking OPC differentiation [59]. Through high-resolution EM analysis, the authors observed microglial cells along with oligodendrocytes and astrocytes at the lesion site. The microglia had the appearance of the reactive type with surface protrusions suggesting EV release, which prompted the authors to investigate the exogenous EVs produced by activated microglia with a Th1 cytokine cocktail (IL-1 $\beta, T N F \alpha$, IFN $\gamma$ ). However, in vitro, proinflammatory-induced microglial EVs were able to directly exert prodifferentiating functions on cultured OPCs; therefore, the authors postulate that the in vivo blockade of remyelination observed may involve the action of other CNS cells, 
namely astrocytes. The same group showed that microglial EVs were able to transform astrocytes into A1 cells that inhibit OPC differentiation. Analysis of microglial factors able to cause the conversion of astrocytes to the A1 type namely IL-1a, C1q and TNF $\alpha$, showed that indeed these mediators were present in i-EVs.

\section{Gray Matter Pathology of Microglia}

As discussed above, it is clear that microglia are intimately involved in white matter pathology in multiple ways. On the contrary, their involvement in gray matter pathology has been less studied. A recent, comprehensive review discusses their involvement in myelin pathology and neurodegeneration, highlighting the fact that, in part, microglia in gray matter follow the same principles as in white matter, but also in some ways diverge from them [156].

Gray matter pathology in MS is at the center of the disease, since it is present from the earliest stages and is linked to the disability MS patients suffer from [157]. Microglia are involved in all aspects of gray matter pathology. As evidenced in other degenerative diseases, microglia in gray matter exert both beneficial and damaging functions [158].

In gray matter demyelination, inflammation is present but not as pronounced as in white matter. It is hypothesized, based on histological observations that report inflammatory infiltrates near cortical (in other words gray matter) lesions, that soluble mediators such as interferon- $\gamma$ and TNF- $\alpha$, two molecules associated with microglial activation, contribute to demyelination. On the other hand, it is postulated that gray matter demyelination occurs secondarily to white matter demyelination. At present, the exact role of microglia in gray matter is not as clear as in white matter regions.

Chronic gray matter lesions, being less inflammatory than white matter lesions, remyelinate to a greater extent [159]. A number of factors may underlie this important observation. It is possible, for example, that gray matter microglia are more efficient in clearing myelin debris, as they do in development, by eliminating ectopic myelin [92]. At the same time, data from rodent models suggest that in gray matter, OPCs may be assisted by microglia in migrating more efficiently [160]. In addition, studies in iron homeostasis, important for myelin synthesis, point to microglia in gray matter as facilitators in iron intake by oligodendrocytes [161]. Thus, gray matter microglia may be allies in remyelinating efforts in the CNS.

In gray matter pathologies, synaptic function is at stake. In many neurodegenerative diseases, including MS, synaptic compromise appears early. Postmortem studies have revealed microglial engulfment and digestion of synaptic components in cerebellar gray matter, thalamus and hippocampus. Inhibitory synapses seem to be selectively targeted in the motor cortex [162]. Rodent models confirm the human studies [162-164].

Other than their damaging effect, however, microglia in gray matter have been shown to protect synaptic health by aiding the survival of synapses to maintain network accuracy [165]. Microglia are essential components of synaptic plasticity, as they induce the generation of postsynaptic structures [166,167].

As neuronal cell bodies, axons and dendrites degenerate, resulting in cell death, and CNS microglia are considered prime culprits. Microglia with a phagocytic phenotype are found apposing neuronal damaged cells, expressing molecules effectuating oxidative stress in demyelinated cortical areas $[168,169]$. A degeneration-associated microglial signature is present in degenerative pathologies, including MS gray matter disease $[170,171]$. MS neurodegeneration also involves the action of astrocytes, and cross-talk between microglia and astrocytes is known to contribute [172].

Although a clear role for neuroprotection has not been established for gray matter microglia, some recent evidence in human postmortem tissue, as well as rodent tissue, point to the possibility that they physically protect neuronal cell bodies [173,174].

In summary, microglia in gray matter, although less studied than their white matter counterparts, participate in demyelination, remyelination, synaptic damage and neurodegeneration by supporting both beneficial and detrimental functions on oligodendrocytes and neurons. Thus, as it is gradually appreciated that microglia organize an extremely diverse and multifaceted response, understanding their actions in both white and gray matter is of paramount importance (Table 1). 
Table 1. Summary table summarizing the functions of microglia during myelin damage and repair and indicating their beneficial or detrimental roles, as well as their source.

\begin{tabular}{|c|c|c|c|}
\hline Function of Microglia & Beneficial or Detrimental Effect & Samples Used in the Study & White or Gray Matter \\
\hline Increase OPC survival & Beneficial & In vitro studies & Both \\
\hline Increase OPC differentiation & Beneficial & In vitro studies & Both \\
\hline Increase OL differentiation & Beneficial & $\begin{array}{l}\text { In vivo studies (cuprizone } \\
\text { induced demyelination model) }\end{array}$ & White matter \\
\hline Increase OPC proliferation & Beneficial & In vitro studies & Both \\
\hline Increase OL survival & Beneficial & In vitro studies & Both \\
\hline Increase OL survival & Beneficial & $\begin{array}{c}\text { In vivo studies (cuprizone } \\
\text { induced demyelination model) }\end{array}$ & White matter \\
\hline Reduce OL apoptosis & Beneficial & $\begin{array}{l}\text { In vivo studies (viral induced } \\
\text { demyelination model) }\end{array}$ & White matter \\
\hline $\begin{array}{c}\text { Responsible for myelin } \\
\text { clearance }\end{array}$ & Beneficial & $\begin{array}{c}\text { In vivo studies (cuprizone } \\
\text { induced demyelination model) }\end{array}$ & White matter \\
\hline $\begin{array}{c}\text { Responsible for myelin } \\
\text { degradation }\end{array}$ & Beneficial & $\begin{array}{l}\text { In vivo studies (LPC induced } \\
\text { demyelination model) }\end{array}$ & White matter \\
\hline Enhance remyelination & Beneficial & $\begin{array}{c}\text { In vivo studies (cuprizone } \\
\text { induced demyelination model) }\end{array}$ & White matter \\
\hline Initiate inflammation & Detrimental & $\begin{array}{c}\text { In vivo studies } \\
\text { (EAE demyelination model) }\end{array}$ & White matter \\
\hline Enhance disease symptoms & Detrimental & $\begin{array}{c}\text { In vivo studies } \\
\text { (EAE demyelination model) }\end{array}$ & White matter \\
\hline $\begin{array}{l}\text { Increase toxicity leading to } \\
\text { impaired OL differentiation }\end{array}$ & Detrimental & In vitro studies & Both \\
\hline $\begin{array}{l}\text { Increase the efficiency of OPC } \\
\text { migration }\end{array}$ & Beneficial & In vivo studies & Gray matter \\
\hline $\begin{array}{c}\text { Facilitate iron intake by } \\
\text { oligodendrocytes }\end{array}$ & Beneficial & Human studies & Gray matter \\
\hline $\begin{array}{l}\text { Engulf and digest synaptic } \\
\text { components }\end{array}$ & Detrimental & Human and in vivo studies & Gray matter \\
\hline Protect synaptic health & Beneficial & In vivo studies & Gray matter \\
\hline $\begin{array}{l}\text { Essential for synaptic } \\
\text { plasticity }\end{array}$ & Beneficial & In vivo studies & Gray matter \\
\hline $\begin{array}{l}\text { Contribute to neuronal cell } \\
\text { body, axonal and dendrite } \\
\text { degeneration }\end{array}$ & Detrimental & Human and in vivo studies & Gray matter \\
\hline
\end{tabular}

\section{Human Stem-Cell-Derived Preclinical Models for the Study of Microglia in Human Pathologies}

In rodents, the use of novel transgenic lines is expected to shed light on the role of microglia in the processes discussed above via tracking and manipulation $[175,176]$. Recent data from single cell analysis also allows in depth characterization of the role of microglia in health and disease. From the limited data so far, regional differences in microglial profiling have emerged in mouse as well as humans $[89,170,177]$. Although they share a core transcriptome, human microglia seem to be more heterogenous and more immune-vigilant [178]. Thus, the question that human-specific pathologies may not be properly recapitulated or modelled in animals, resurfaces.

It is, therefore, with anticipation that data from the differentiation of human-induced pluripotent stem cells (iPSCs) is projected to elucidate human-related pathology [179-181]. These technologies coupled with other state-of-the-art approaches, such as 3D organoids 
that enable cross-talk between cellular populations, pave a promising pathway. Nevertheless, as in all in vitro models, iPSC-derived microglia are isolated from their microenvironment with unknown consequences. Manipulating human microglia derived from iPSCs, but transplanted in a mouse brain, may provide important clues.

As the ultimate goal is to target microglia for MS therapy, all of the constraints discussed above, namely the regional, temporal and functional heterogeneity that this versatile cellular population exhibits, need to be carefully considered. We still need to reveal aspects of their homeostatic physiology and pathophysiology in order to be able to harness some of their beneficial attributes.

\section{Microbiome, Microglia and Oligodendrocytes}

The emerging field of microbiome research has already provided intriguing information on the relationship of the microbiome and CNS function. In particular, the microbiomegut-brain axis is shown to play a significant role in neuroinflammation. Functional studies have linked the microbiome to a number of neurodegenerative diseases including MS [182-186]. MS patients possess a distinct microbiome, and, in turn, the microbiome of MS patients induces disease in rodents $[183,187,188]$. Microglia (as well as other innate immune cells) express toll-like and other pattern recognition receptors that are able to detect microbial and other molecules associated with infections. Upon recognition, microglia release proinflammatory cytokines. Thus, microbe-induced inflammation could play a role in autoimmunity and inflammatory demyelination seen in MS or MS-like pathologies in animals [102]. Gut microbiota could contribute to MS pathogenesis by priming myelinreactive T cells, as has been observed in EAE models [189]. Prompted by the fact that in MS patients a reduction of bacteria producing short fatty acids, in particular butyrate, in a recent work butyrate was administered to cuprizone-treated mice as well as to LPC-treated organotypic slices resulting in amelioration of demyelination in both cases. Moreover, butyrate seems to affect oligodendrocytes directly without microglial involvement, and it also promoted differentiation of immature oligodendrocytes [190]. Maternal administration of probiotics decreased IL- $1 \beta$-induced inflammation and was associated with decreased microglial activation, while OPC development was promoted [191]. Recent work on the other hand, does not support a role of microbiota in modulating endogenous CNS remyelination as assessed by OPC differentiation [192]. More mechanistic studies are necessary to establish a direct role of the microbiome in the process of myelination and associated pathologies, although the exciting progress in this field holds great promise.

\section{Concluding Remarks}

In conclusion, homeostasis of CNS myelination is contingent upon the cross-talk between oligodendrocytes, microglia and astrocytes (astrocytes are not discussed in this work but for comprehensive reviews see [172,193]). In the various demyelinating pathologies, this cross-talk is essential in all phases of disease manifestation (inflammation, demyelination, remyelination) regulating the functions of each cellular population. Moreover, these interactions are pleiotropic and dynamic in space and time. Therefore, it is crucial to understand the cellular and molecular nature of the complex dynamics of such interactions, which show both positive and negative functions during damage and repair.

A number of unresolved issues regarding this intricate interplay of microglia and oligodendrocytes in health and disease await careful investigation. Among them, the clarification of the conditions driving microglia towards their beneficial or damaging roles, especially in gray matter of demyelinating disease models, is paramount. Single cell analysis has already been useful, and will continue to be so, in deciphering context-specific genetic programs underlying microglia and oligodendrocyte functions. Research directions that are important in myelin repair, such as neuronal activity, the microbiome as well as the exploitation of human-derived stem cells, are promising. The hope is that knowledge on the modulation of beneficial versus detrimental roles of microglia will be used to devise therapeutic strategies with an emphasis on oligodendrocyte proliferation/maturation. 
Funding: Funding was provided by the ARSEP foundation and Grant T2E $\Delta K-00501$ under the Operational Programme “Competitiveness, Entrepreneurship and Innovation 2021-2023".

Acknowledgments: The authors would like to thank members of the Karagogeos laboratory and M. Grigoriou for helpful comments.

Conflicts of Interest: The authors declare no conflict of interest.

\section{References}

1. Stadelmann, C.; Timmler, S.; Barrantes-Freer, A.; Simons, M. Myelin in the Central Nervous System: Structure, Function, and Pathology. Physiol. Rev. 2019, 99, 1381-1431. [CrossRef]

2. Nave, K.-A.; Werner, H.B. Myelination of the Nervous System: Mechanisms and Functions. Annu. Rev. Cell Dev. Biol. 2014, 30, 503-533. [CrossRef]

3. Fünfschilling, U.; Supplie, L.M.; Mahad, D.; Boretius, S.; Saab, A.S.; Edgar, J.; Brinkmann, B.G.; Kassmann, C.M.; Tzvetanova, I.D.; Möbius, W.; et al. Glycolytic oligodendrocytes maintain myelin and long-term axonal integrity. Nature 2012, 485, 517-521. [CrossRef]

4. Lee, J.K.; Zheng, B. Role of myelin-associated inhibitors in axonal repair after spinal cord injury. Exp. Neurol. 2012, 235, 33-42. [CrossRef]

5. Lee, S.; Leach, M.; Redmond, S.; Chong, S.Y.C.; Mellon, S.H.; Tuck, S.J.; Feng, Z.-Q.; Corey, J.M.; Chan, J.R. A culture system to study oligodendrocyte myelination processes using engineered nanofibers. Nat. Methods 2012, 9, 917-922. [CrossRef]

6. Saab, A.S.; Nave, K.-A. Myelin dynamics: Protecting and shaping neuronal functions. Curr. Opin. Neurobiol. 2017, 47, 104-112. [CrossRef]

7. Fields, R.D. White matter in learning, cognition and psychiatric disorders. Trends Neurosci. 2008, 31, 361-370. [CrossRef] [PubMed]

8. Forbes, T.A.; Gallo, V. All Wrapped Up: Environmental Effects on Myelination. Trends Neurosci. 2017, 40, 572-587. [CrossRef] [PubMed]

9. Monje, M. Myelin Plasticity and Nervous System Function. Annu. Rev. Neurosci. 2018, 41, 61-76. [CrossRef] [PubMed]

10. Ronzano, R.; Thetiot, M.; Lubetzki, C.; Desmazieres, A. Myelin Plasticity and Repair: Neuro-Glial Choir Sets the Tuning. Front. Cell. Neurosci. 2020, 14, 42. [CrossRef] [PubMed]

11. Zuchero, J.B.; Barres, B.A. Intrinsic and extrinsic control of oligodendrocyte development. Curr. Opin. Neurobiol. 2013, 23, 914-920. [CrossRef]

12. Rowitch, D.H.; Kriegstein, A.R. Developmental genetics of vertebrate glial-cell specification. Nat. Cell Biol. 2010, 468, 214-222. [CrossRef]

13. Fancy, S.P.; Chan, J.R.; Baranzini, S.E.; Franklin, R.J.; Rowitch, D.H. Myelin Regeneration: A Recapitulation of Development? Annu. Rev. Neurosci. 2011, 34, 21-43. [CrossRef] [PubMed]

14. McKenzie, I.A.; Ohayon, D.; Li, H.; de Faria, J.P.; Emery, B.; Tohyama, K.; Richardson, W.D. Motor skill learning requires active central myelination. Science 2014, 346, 318-322. [CrossRef] [PubMed]

15. Bacmeister, C.M.; Barr, H.; McClain, C.R.; Thornton, M.A.; Nettles, D.; Welle, C.G.; Hughes, E.G. Motor learning promotes remyelination via new and surviving oligodendrocytes. Nat. Neurosci. 2020, 23, 819-831. [CrossRef]

16. Polman, C.H.; Reingold, S.C.; Banwell, B.; Clanet, M.; Cohen, J.A.; Filippi, M.; Fujihara, K.; Havrdova, E.; Hutchinson, M.; Kappos, L.; et al. Diagnostic criteria for multiple sclerosis: 2010 Revisions to the McDonald criteria. Ann. Neurol. 2011, 69, $292-302$. [CrossRef] [PubMed]

17. Thompson, A.J.; Baranzini, S.E.; Geurts, J.; Hemmer, B.; Ciccarelli, O. Multiple sclerosis. Lancet 2018, 391, 1622-1636. [CrossRef]

18. Reich, D.S.; Lucchinetti, C.F.; Calabresi, P. Multiple Sclerosis. N. Engl. J. Med. 2018, 378, 169-180. [CrossRef] [PubMed]

19. Barnett, M.H.; Prineas, J.W. Relapsing and remitting multiple sclerosis: Pathology of the newly forming lesion. Ann. Neurol. 2004, 55, 458-468. [CrossRef]

20. Traka, M.; Podojil, J.R.; McCarthy, D.P.; Miller, S.D.; Popko, B. Oligodendrocyte death results in immune-mediated CNS demyelination. Nat. Neurosci. 2015, 19, 65-74. [CrossRef] [PubMed]

21. Dendrou, C.; Fugger, L.; Friese, M.A. Immunopathology of multiple sclerosis. Nat. Rev. Immunol. 2015, 15, 545-558. [CrossRef]

22. Merrill, J.E. In Vitro and In Vivo Pharmacological Models to Assess Demyelination and Remyelination. Neuropsychopharmacology 2008, 34, 55-73. [CrossRef]

23. Sanabria-Castro, A.; Flores-Díaz, M.; Alape-Girón, A. Biological models in multiple sclerosis. J. Neurosci. Res. 2020, 98, 491-508. [CrossRef]

24. Ozawa, K.; Suchanek, G.; Breitschopf, H.; Br€Ck, W.; Budka, H.; Jellinger, K.; Lassmann, H. Patterns of oligodendroglia pathology in multiple sclerosis. Brain 1994, 117, 1311-1322. [CrossRef] [PubMed]

25. Goldschmidt, T.; Antel, J.; Konig, F.B.; Bruck, W.; Kuhlmann, T. Remyelination capacity of the MS brain decreases with disease chronicity. Neurology 2009, 72, 1914-1921. [CrossRef] [PubMed]

26. Patrikios, P.; Stadelmann, C.; Kutzelnigg, A.; Rauschka, H.; Schmidbauer, M.; Laursen, H.; Sorensen, P.S.; Brück, W.; Lucchinetti, C.; Lassmann, H. Remyelination is extensive in a subset of multiple sclerosis patients. Brain 2006, 129, 3165-3172. [CrossRef] [PubMed] 
27. Frischer, J.; Ms, S.D.W.; Guo, Y.; Kale, N.; Parisi, J.E.; Pirko, I.; Mandrekar, J.; Bramow, S.; Metz, I.; Brück, W.; et al. Clinical and pathological insights into the dynamic nature of the white matter multiple sclerosis plaque. Ann. Neurol. 2015, 78, 710-721. [CrossRef] [PubMed]

28. Franklin, R.; Ffrench-Constant, C. Regenerating CNS myelin-from mechanisms to experimental medicines. Nat. Rev. Neurosci. 2017, 18, 753-769. [CrossRef] [PubMed]

29. Mason, J.L.; Suzuki, K.; Chaplin, D.; Matsushima, G.K. Interleukin-1ß Promotes Repair of the CNS. J. Neurosci. 2001, 21, 7046-7052. [CrossRef] [PubMed]

30. Huebner, E.A.; Strittmatter, S.M. Axon Regeneration in the Peripheral and Central Nervous Systems. In Chemistry and Biology of Pteridines and Folates; Springer Science and Business Media LLC: Berlin, Germany, 2009; Volume 48, pp. 305-360.

31. Prineas, J.W.; Barnard, R.O.; Kwon, E.E.; Sharer, L.R.; Cho, E.-S. Multiple sclerosis: Remyelination of nascent lesions: Remyelination of nascent lesions. Ann. Neurol. 1993, 33, 137-151. [CrossRef]

32. Rodriguez, E.G.; Wegner, C.; Kreutzfeldt, M.; Neid, K.; Thal, D.R.; Jürgens, T.; Brück, W.; Stadelmann, C.; Merkler, D. Oligodendroglia in cortical multiple sclerosis lesions decrease with disease progression, but regenerate after repeated experimental demyelination. Acta Neuropathol. 2014, 128, 231-246. [CrossRef]

33. Lucchinetti, C.; Brück, W.; Parisi, J.; Scheithauer, B.; Rodriguez, M.; Lassmann, H. A quantitative analysis of oligodendrocytes in multiple sclerosis lesions. Brain 1999, 122, 2279-2295. [CrossRef]

34. Boyd, A.; Zhang, H.; Williams, A. Insufficient OPC migration into demyelinated lesions is a cause of poor remyelination in MS and mouse models. Acta Neuropathol. 2013, 125, 841-859. [CrossRef]

35. Kipp, M.; Clarner, T.; Dang, J.; Copray, S.; Beyer, C. The cuprizone animal model: New insights into an old story. Acta Neuropathol. 2009, 118, 723-736. [CrossRef]

36. Redwine, J.M.; Armstrong, R.C. In vivo proliferation of oligodendrocyte progenitors expressing PDGF $\alpha$ R during early remyelination. J. Neurobiol. 1998, 37, 413-428. [CrossRef]

37. Di Bello, I.C.; Dawson, M.; Levine, J.; Reynolds, R. Generation of oligodendroglial progenitors in acute inflammatory demyelinating lesions of the rat brain stem is associated with demyelination rather than inflammation. J. Neurocytol. 1999, $28,365-381$. [CrossRef]

38. Fancy, S.P.; Zhao, C.; Franklin, R. Increased expression of Nkx2.2 and Olig2 identifies reactive oligodendrocyte progenitor cells responding to demyelination in the adult CNS. Mol. Cell. Neurosci. 2004, 27, 247-254. [CrossRef] [PubMed]

39. Moyon, S.; Dubessy, A.L.; Aigrot, M.S.; Trotter, M.; Huang, J.; Dauphinot, L.; Potier, M.-C.; Kerninon, C.; Parsadaniantz, S.M.; Franklin, R.; et al. Demyelination Causes Adult CNS Progenitors to Revert to an Immature State and Express Immune Cues That Support Their Migration. J. Neurosci. 2015, 35, 4-20. [CrossRef] [PubMed]

40. Fancy, S.P.; Baranzini, S.E.; Zhao, C.; Yuk, D.-I.; Irvine, K.-A.; Kaing, S.; Sanai, N.; Franklin, R.J.; Rowitch, D.H. Dysregulation of the Wnt pathway inhibits timely myelination and remyelination in the mammalian CNS. Genes Dev. 2009, 23, 1571-1585. [CrossRef]

41. Wang, S.; Sdrulla, A.D.; Disibio, G.; Bush, G.; Nofziger, D.; Hicks, C.; Weinmaster, G.; Barres, B.A. Notch Receptor Activation Inhibits Oligodendrocyte Differentiation. Neuron 1998, 21, 63-75. [CrossRef]

42. Neumann, B.; Segel, M.; Chalut, K.J.; Franklin, R.J. Remyelination and ageing: Reversing the ravages of time. Mult. Scler. J. 2019, 25, 1835-1841. [CrossRef]

43. Gensert, J.M.; Goldman, E.J. Endogenous Progenitors Remyelinate Demyelinated Axons in the Adult CNS. Neuron 1997, 19, 197-203. [CrossRef]

44. Zawadzka, M.; Rivers, L.E.; Fancy, S.P.; Zhao, C.; Tripathi, R.; Jamen, F.; Young, K.; Goncharevich, A.; Pohl, H.; Rizzi, M.; et al. CNS-Resident Glial Progenitor/Stem Cells Produce Schwann Cells as well as Oligodendrocytes during Repair of CNS Demyelination. Cell Stem Cell 2010, 6, 578-590. [CrossRef]

45. Menn, B.; García-Verdugo, J.M.; Yaschine, C.; Gonzalez-Perez, O.; Rowitch, D.; Alvarez-Buylla, A. Origin of Oligodendrocytes in the Subventricular Zone of the Adult Brain. J. Neurosci. 2006, 26, 7907-7918. [CrossRef]

46. Samanta, J.; Grund, E.M.; Silva, H.M.; Lafaille, J.J.; Fishell, G.; Salzer, J.L. Inhibition of Gli1 mobilizes endogenous neural stem cells for remyelination. Nat. Cell Biol. 2015, 526, 448-452. [CrossRef]

47. Kirby, L.; Jin, J.; Cardona, J.G.; Smith, M.D.; Martin, K.A.; Wang, J.; Strasburger, H.; Herbst, L.; Alexis, M.; Karnell, J.; et al. Oligodendrocyte precursor cells present antigen and are cytotoxic targets in inflammatory demyelination. Nat. Commun. 2019, 10, 1-20. [CrossRef] [PubMed]

48. Harrington, E.P.; Bergles, D.E.; Calabresi, P.A. Immune cell modulation of oligodendrocyte lineage cells. Neurosci. Lett. 2020, 715, 134601. [CrossRef] [PubMed]

49. Jäkel, S.; Agirre, E.; Falcão, A.M.; van Bruggen, D.; Lee, K.W.; Knuesel, I.; Malhotra, D.; Ffrench-Constant, C.; Williams, A.; Castelo-Branco, G. Altered human oligodendrocyte heterogeneity in multiple sclerosis. Nature 2019, 566, 543-547. [CrossRef] [PubMed]

50. Falcão, A.M.; van Bruggen, D.; Marques, S.; Meijer, M.; Jäkel, S.; Agirre, E.; Samudyata; Floriddia, E.M.; Vanichkina, D.P.; Ffrench-Constant, C.; et al. Disease-specific oligodendrocyte lineage cells arise in multiple sclerosis. Nat. Med. 2018, 24, 1837-1844. [CrossRef] [PubMed] 
51. Krämer-Albers, E.-M.; Bretz, N.; Tenzer, S.; Winterstein, C.; Möbius, W.; Berger, H.; Nave, K.-A.; Schild, H.; Trotter, J. Oligodendrocytes secrete exosomes containing major myelin and stress-protective proteins: Trophic support for axons? Proteom. Clin. Appl. 2007, 1, 1446-1461. [CrossRef] [PubMed]

52. Krämer-Albers, E.-M. Extracellular vesicles in the oligodendrocyte microenvironment. Neurosci. Lett. 2020, 725, 134915. [CrossRef] [PubMed]

53. Frühbeis, C.; Fröhlich, D.; Kuo, W.P.; Amphornrat, J.; Thilemann, S.; Saab, A.S.; Kirchhoff, F.; Möbius, W.; Goebbels, S.; Nave, K.-A.; et al. Neurotransmitter-Triggered Transfer of Exosomes Mediates Oligodendrocyte-Neuron Communication. PLoS Biol. 2013, 11, e1001604. [CrossRef] [PubMed]

54. Frühbeis, C.; Fröhlich, D.; Kuo, W.P.; Krämer-Albers, E.-M. Extracellular vesicles as mediators of neuron-glia communication. Front. Cell. Neurosci. 2013, 7, 182. [CrossRef]

55. Fitzner, D.; Schnaars, M.; van Rossum, D.; Krishnamoorthy, G.; Dibaj, P.; Bakhti, M.; Regen, T.; Hanisch, U.-K.; Simons, M. Selective transfer of exosomes from oligodendrocytes to microglia by macropinocytosis. J. Cell Sci. 2011, 124, 447-458. [CrossRef]

56. Colombo, F.; Bastoni, M.; Nigro, A.; Podini, P.; Finardi, A.; Casella, G.; Ramesh, M.; Farina, C.; Verderio, C.; Furlan, R. Cytokines stimulate the release of microvesicles from myeloid cells independently from the P2X7 receptor/acid sphingomyelinase pathway. Front. Immunol. 2018, 9, 204. [CrossRef]

57. Drago, F.; Lombardi, M.; Prada, I.; Gabrielli, M.; Joshi, P.; Cojoc, D.; Franck, J.; Fournier, I.; Vizioli, J.; Verderio, C. ATP Modifies the Proteome of Extracellular Vesicles Released by Microglia and Influences Their Action on Astrocytes. Front. Pharmacol. 2017, 8, 910. [CrossRef]

58. Bakhti, M.; Winter, C.; Simons, M. Inhibition of Myelin Membrane Sheath Formation by Oligodendrocyte-derived Exosome-like Vesicles. J. Biol. Chem. 2011, 286, 787-796. [CrossRef]

59. Lombardi, M.; Parolisi, R.; Scaroni, F.; Bonfanti, E.; Gualerzi, A.; Gabrielli, M.; De Rosbo, N.K.; Uccelli, A.; Giussani, P.; Viani, P.; et al. Detrimental and protective action of microglial extracellular vesicles on myelin lesions: Astrocyte involvement in remyelination failure. Acta Neuropathol. 2019, 138, 987-1012. [CrossRef] [PubMed]

60. Soulet, D.; Rivest, S. Microglia. Curr. Biol. 2008, 18, R506-R508. [CrossRef]

61. Prinz, M.; Erny, D.; Hagemeyer, M. Ontogeny and homeostasis of CNS myeloid cells. Nat. Immunol. 2017, 18, 385-392. [CrossRef]

62. Thion, M.S.; Garel, S. On place and time: Microglia in embryonic and perinatal brain development. Curr. Opin. Neurobiol. 2017, 47, 121-130. [CrossRef]

63. Hong, S.; Dissing-Olesen, L.; Stevens, B. New insights on the role of microglia in synaptic pruning in health and disease. Curr. Opin. Neurobiol. 2016, 36, 128-134. [CrossRef]

64. Prinz, M.; Jung, S.; Priller, J. Microglia Biology: One Century of Evolving Concepts. Cell 2019, 179, 292-311. [CrossRef]

65. Orihuela, R.; McPherson, C.A.; Harry, G.J. Microglial M1/M2 polarization and metabolic states. Br. J. Pharmacol. 2016, 173, 649-665. [CrossRef]

66. Hammond, T.R.; Dufort, C.; Dissing-Olesen, L.; Giera, S.; Young, A.; Wysoker, A.; Walker, A.J.; Gergits, F.; Segel, M.; Nemesh, J.; et al. Single-Cell RNA Sequencing of Microglia throughout the Mouse Lifespan and in the Injured Brain Reveals Complex Cell-State Changes. Immunity 2019, 50, 253-271.e6. [CrossRef]

67. Frost, J.L.; Schafer, D.P. Microglia: Architects of the Developing Nervous System. Trends Cell Biol. 2016, 26, 587-597. [CrossRef] [PubMed]

68. Sierra, A.; Encinas, J.M.; Deudero, J.J.P.; Chancey, J.; Enikolopov, G.; Overstreet-Wadiche, L.S.; Tsirka, S.E.; Maletic-Savatic, M. Microglia Shape Adult Hippocampal Neurogenesis through Apoptosis-Coupled Phagocytosis. Cell Stem Cell 2010, 7, $483-495$. [CrossRef]

69. Tremblay, M.-È.; Lowery, R.L.; Majewska, A.K. Microglial Interactions with Synapses Are Modulated by Visual Experience. PLoS Biol. 2010, 8, e1000527. [CrossRef] [PubMed]

70. Wake, H.; Moorhouse, A.; Miyamoto, A.; Nabekura, J. Microglia: Actively surveying and shaping neuronal circuit structure and function. Trends Neurosci. 2013, 36, 209-217. [CrossRef] [PubMed]

71. Schafer, D.P.; Lehrman, E.K.; Kautzman, A.G.; Koyama, R.; Mardinly, A.; Yamasaki, R.; Ransohoff, R.M.; Greenberg, M.E.; Barres, B.A.; Stevens, B. Microglia Sculpt Postnatal Neural Circuits in an Activity and Complement-Dependent Manner. Neuron 2012, 74, 691-705. [CrossRef]

72. Sipe, G.O.; Lowery, R.L.; Tremblay, M.-E.; Kelly, E.A.; LaMantia, C.E.; Majewska, A.K. Microglial P2Y12 is necessary for synaptic plasticity in mouse visual cortex. Nat. Commun. 2016, 7, 10905. [CrossRef] [PubMed]

73. Lehrman, E.K.; Wilton, D.K.; Litvina, E.Y.; Welsh, C.A.; Chang, S.T.; Frouin, A.; Walker, A.J.; Heller, M.D.; Umemori, H.; Chen, C.; et al. CD47 Protects Synapses from Excess Microglia-Mediated Pruning during Development. Neuron 2018, 100, 120-134.e6. [CrossRef] [PubMed]

74. Squarzoni, P.; Oller, G.; Hoeffel, G.; Pont-Lezica, L.; Rostaing, P.; Low, D.; Bessis, A.; Ginhoux, F.; Garel, S. Microglia Modulate Wiring of the Embryonic Forebrain. Cell Rep. 2014, 8, 1271-1279. [CrossRef] [PubMed]

75. Hagemeyer, N.; Hanft, K.-M.; Akriditou, M.-A.; Unger, N.; Park, E.S.; Stanley, E.R.; Staszewski, O.; Dimou, L.; Prinz, M. Microglia contribute to normal myelinogenesis and to oligodendrocyte progenitor maintenance during adulthood. Acta Neuropathol. 2017, 134, 441-458. [CrossRef] 
76. Wlodarczyk, A.; Holtman, I.R.; Krueger, M.; Yogev, N.; Bruttger, J.; Khorooshi, R.; Benmamar-Badel, A.; de Boer-Bergsma, J.J.; Martin, N.A.; Karram, K.; et al. A novel microglial subset plays a key role in myelinogenesis in developing brain. EMBO J. 2017, 36, 3292-3308. [CrossRef] [PubMed]

77. Althaus, H.H.; Klöppner, S.; Klopfleisch, S.; Schmitz, M. Oligodendroglial Cells and Neurotrophins: A Polyphonic Cantata in Major and Minor. J. Mol. Neurosci. 2008, 35, 65-79. [CrossRef]

78. Shigemoto-Mogami, Y.; Hoshikawa, K.; Goldman, J.E.; Sekino, Y.; Sato, K. Microglia Enhance Neurogenesis and Oligodendrogenesis in the Early Postnatal Subventricular Zone. J. Neurosci. 2014, 34, 2231-2243. [CrossRef]

79. Hamilton, S.; Rome, L.H. Stimulation of in vitro myelin synthesis by microglia. Glia 1994, 11, 326-335. [CrossRef]

80. Nicholas, R.S.J.; Wing, M.G.; Compston, A. Nonactivated microglia promote oligodendrocyte precursor survival and maturation through the transcription factor NF-kB. Eur. J. Neurosci. 2001, 13, 959-967. [CrossRef]

81. Nicholas, R.; Stevens, S.; Wing, M.; Compston, D. Microglia-derived IGF-2 prevents TNF $\alpha$ induced death of mature oligodendrocytes in vitro. J. Neuroimmunol. 2002, 124, 36-44. [CrossRef]

82. Pasquini, L.A.; Millet, V.; Hoyos, H.C.; Giannoni, J.P.; Croci, D.O.; Marder, M.; Liu, F.T.; Rabinovich, G.A.; Pasquini, J.M. Galectin-3 drives oligodendrocyte differentiation to control myelin integrity and function. Cell Death Differ. 2011, 18, 1746-1756. [CrossRef] [PubMed]

83. Pang, Y.; Fan, L.-W.; Tien, L.-T.; Dai, X.; Zheng, B.; Cai, Z.; Lin, R.C.S.; Bhatt, A. Differential roles of astrocyte and microglia in supporting oligodendrocyte development and myelination in vitro. Brain Behav. 2013, 3, 503-514. [CrossRef]

84. Miron, V.E.; Boyd, A.; Zhao, J.-W.; Yuen, T.J.; Ruckh, J.M.; Shadrach, J.L.; van Wijngaarden, P.; Wagers, A.J.; Williams, A.; Franklin, R.; et al. M2 microglia and macrophages drive oligodendrocyte differentiation during CNS remyelination. Nat. Neurosci. 2013, 16, 1211-1218. [CrossRef]

85. Butovsky, O.; Ziv, Y.; Schwartz, A.; Landa, G.; Talpalar, A.E.; Pluchino, S.; Martino, G.; Schwartz, M. Microglia activated by IL-4 or IFN- $\gamma$ differentially induce neurogenesis and oligodendrogenesis from adult stem/progenitor cells. Mol. Cell. Neurosci. 2006, 31, 149-160. [CrossRef] [PubMed]

86. Erblich, B.; Zhu, L.; Etgen, A.M.; Dobrenis, K.; Pollard, J.W. Absence of Colony Stimulation Factor-1 Receptor Results in Loss of Microglia, Disrupted Brain Development and Olfactory Deficits. PLoS ONE 2011, 6, e26317. [CrossRef] [PubMed]

87. Geladaris, A.; Häusler, D.; Weber, M. Microglia: The Missing Link to Decipher and Therapeutically Control MS Progression? Int. J. Mol. Sci. 2021, 22, 3461. [CrossRef] [PubMed]

88. Grabert, K.; Michoel, T.; Karavolos, M.H.; Clohisey, S.; Baillie, J.K.; Stevens, M.; Freeman, T.; Summers, K.; McColl, B.W. Microglial brain region-dependent diversity and selective regional sensitivities to aging. Nat. Neurosci. 2016, 19, 504-516. [CrossRef]

89. Böttcher, C.; Psy, N.; Schlickeiser, S.; Sneeboer, M.A.M.; Kunkel, D.; Knop, A.; Paza, E.; Fidzinski, P.; Kraus, L.; Snijders, G.J.L.; et al. Human microglia regional heterogeneity and phenotypes determined by multiplexed single-cell mass cytometry. Nat. Neurosci. 2019, 22, 78-90. [CrossRef]

90. O'Koren, E.G.; Yu, C.; Klingeborn, M.; Wong, A.Y.; Prigge, C.L.; Mathew, R.; Kalnitsky, J.; Msallam, R.A.; Silvin, A.; Kay, J.N.; et al. Microglial Function Is Distinct in Different Anatomical Locations during Retinal Homeostasis and Degeneration. Immunology 2019, 50, 723-737.e7. [CrossRef] [PubMed]

91. Ayata, P.; Badimon, A.; Strasburger, H.J.; Duff, M.K.; Montgomery, S.; Loh, Y.-H.E.; Ebert, A.; Pimenova, A.A.; Ramirez, B.R.; Chan, A.; et al. Epigenetic regulation of brain region-specific microglia clearance activity. Nat. Neurosci. 2018, 21, 1049-1060. [CrossRef]

92. Hughes, A.N.; Appel, B. Microglia phagocytose myelin sheaths to modify developmental myelination. Nat. Neurosci. 2020, 23, 1055-1066. [CrossRef] [PubMed]

93. Nemes-Baran, A.D.; White, D.R.; DeSilva, T.M. Fractalkine-Dependent Microglial Pruning of Viable Oligodendrocyte Progenitor Cells Regulates Myelination. Cell Rep. 2020, 32, 108047. [CrossRef] [PubMed]

94. Davalos, D.; Grutzendler, J.; Yang, G.; Kim, J.V.; Zuo, Y.; Jung, S.; Littman, D.R.; Dustin, M.; Gan, W.-B. ATP mediates rapid microglial response to local brain injury in vivo. Nat. Neurosci. 2005, 8, 752-758. [CrossRef]

95. Nimmerjahn, A.; Kirchhoff, F.; Helmchen, F. Resting Microglial Cells Are Highly Dynamic Surveillants of Brain Parenchyma in Vivo. Science 2005, 308, 1314-1318. [CrossRef] [PubMed]

96. Kettenmann, H.; Kirchhoff, F.; Verkhratsky, A. Microglia: New Roles for the Synaptic Stripper. Neuron 2013, 77, 10-18. [CrossRef]

97. Tremblay, M.-Ė; Stevens, B.; Sierra, A.; Wake, H.; Bessis, A.; Nimmerjahn, A. The Role of Microglia in the Healthy Brain. J. Neurosci. 2011, 31, 16064-16069. [CrossRef]

98. Madry, C.; Kyrargyri, V.; Carcamo, I.L.A.; Jolivet, R.; Kohsaka, S.; Bryan, R.M.; Attwell, D. Microglial Ramification, Surveillance, and Interleukin-1 $\beta$ Release Are Regulated by the Two-Pore Domain K+ Channel THIK-1. Neuron 2018, 97, 299-312.e6. [CrossRef]

99. Gordon, S.; Taylor, P. Monocyte and macrophage heterogeneity. Nat. Rev. Immunol. 2005, 5, 953-964. [CrossRef]

100. Colton, C.A. Heterogeneity of Microglial Activation in the Innate Immune Response in the Brain. J. Neuroimmune Pharmacol. 2009, 4, 399-418. [CrossRef]

101. Pons, V.; Rivest, S. Beneficial Roles of Microglia and Growth Factors in MS, a Brief Review. Front. Cell. Neurosci. $2020,14,284$. [CrossRef]

102. Hänninen, A. Infections in MS: An innate immunity perspective. Acta Neurol. Scand. 2017, 136, 10-14. [CrossRef] [PubMed]

103. Triarhou, L.C.; Herndon, R.M. Effect of macrophage inactivation on the neuropathology of lysolecithin-induced demyelination. Br. J. Exp. Pathol. 1985, 66, 293-301. 
104. Brück, W.; Porada, P.; Poser, S.; Rieckmann, P.; Hanefeld, F.; Kretzschmarch, H.A.; Lassmann, H. Monocyte/macrophage differentiation in early multiple sclerosis lesions. Ann. Neurol. 1995, 38, 788-796. [CrossRef] [PubMed]

105. Kotter, M.; Setzu, A.; Sim, F.; Van Rooijen, N.; Franklin, R.J. Macrophage depletion impairs oligodendrocyte remyelination following lysolecithin-induced demyelination. Glia 2001, 35, 204-212. [CrossRef] [PubMed]

106. Prineas, J.W.; Kwon, E.E.; Goldenberg, P.Z.; Ilyas, A.A.; Quarles, R.H.; Benjamins, A.J.; Sprinkle, T.J. Multiple sclerosis. Oligodendrocyte proliferation and differentiation in fresh lesions. Lab. Investig. 1989, 61, 489-503. [PubMed]

107. Goldstein, E.; Church, J.S.; Hesp, Z.C.; Popovich, P.G.; McTigue, D.M. A silver lining of neuroinflammation: Beneficial effects on myelination. Exp. Neurol. 2016, 283, 550-559. [CrossRef] [PubMed]

108. Rawji, K.S.; Mishra, M.K.; Yong, V.W. Regenerative Capacity of Macrophages for Remyelination. Front. Cell Dev. Biol. 2016, 4. [CrossRef]

109. Lloyd, A.F.; Miron, V.E. The pro-remyelination properties of microglia in the central nervous system. Nat. Rev. Neurol. 2019, 15, 447-458. [CrossRef]

110. Yong, H.Y.F.; Rawji, K.S.; Ghorbani, S.; Xue, M.; Yong, V.W. The benefits of neuroinflammation for the repair of the injured central nervous system. Cell. Mol. Immunol. 2019, 16, 540-546. [CrossRef]

111. Zhang, X.; Surguladze, N.; Slagle-Webb, B.; Cozzi, A.; Connor, J.R. Cellular iron status influences the functional relationship between microglia and oligodendrocytes. Glia 2006, 54, 795-804. [CrossRef]

112. Vora, P.; Pillai, P.; Mustapha, J.; Kowal, C.; Shaffer, S.; Bose, R.; Namaka, M.; Frost, E.E. CXCL1 regulation of oligodendrocyte progenitor cell migration is independent of calcium signaling. Exp. Neurol. 2012, 236, 259-267. [CrossRef]

113. Hosking, M.P.; Tirotta, E.; Ransohoff, R.M.; Lane, T.E. CXCR2 Signaling Protects Oligodendrocytes and Restricts Demyelination in a Mouse Model of Viral-Induced Demyelination. PLoS ONE 2010, 5, e11340. [CrossRef] [PubMed]

114. Omari, K.M.; Lutz, S.; Santambrogio, L.; Lira, S.A.; Raine, C.S. Neuroprotection and Remyelination after Autoimmune Demyelination in Mice that Inducibly Overexpress CXCL1. Am. J. Pathol. 2009, 174, 164-176. [CrossRef] [PubMed]

115. Trebst, C.; König, F.; Ransohoff, R.; Brück, W.; Stangel, M. CCR5 expression on macrophages/microglia is associated with early remyelination in multiple sclerosis lesions. Mult. Scler. J. 2008, 14, 728-733. [CrossRef] [PubMed]

116. Kotter, M.; Li, W.-W.; Zhao, C.; Franklin, R. Myelin Impairs CNS Remyelination by Inhibiting Oligodendrocyte Precursor Cell Differentiation. J. Neurosci. 2006, 26, 328-332. [CrossRef]

117. Skripuletz, T.; Hackstette, D.; Bauer, K.; Gudi, V.; Pul, R.; Voss, E.; Berger, K.; Kipp, M.; Baumgärtner, W.; Stangel, M. Astrocytes regulate myelin clearance through recruitment of microglia during cuprizone-induced demyelination. Brain 2012, 136, 147-167. [CrossRef]

118. Cantuti-Castelvetri, L.; Fitzner, D.; Bosch-Queralt, M.; Weil, M.-T.; Su, M.; Sen, P.; Ruhwedel, T.; Mitkovski, M.; Trendelenburg, G.; Lütjohann, D.; et al. Defective cholesterol clearance limits remyelination in the aged central nervous system. Science 2018, 359, 684-688. [CrossRef]

119. Hoyos, H.; Rinaldi, M.; Mendez-Huergo, S.; Marder, M.; Rabinovich, G.; Pasquini, J.; Pasquini, L. Galectin-3 controls the response of microglial cells to limit cuprizone-induced demyelination. Neurobiol. Dis. 2014, 62, 441-455. [CrossRef]

120. Selvaraju, R.; Bernasconi, L.; Losberger, C.; Graber, P.; Kadi, L.; Avellana-Adalid, V.; Picard-Riera, N.; Evercooren, A.B.-V.; Cirillo, R.; Kosco-Vilbois, M.; et al. Osteopontin is upregulated during in vivo demyelination and remyelination and enhances myelin formation in vitro. Mol. Cell. Neurosci. 2004, 25, 707-721. [CrossRef]

121. Calderon, T.M.; Eugenin, E.A.; Lopez, L.; Kumar, S.S.; Hesselgesser, J.; Raine, C.S.; Berman, J.W. A role for CXCL12 (SDF$1 \alpha)$ in the pathogenesis of multiple sclerosis: Regulation of CXCL12 expression in astrocytes by soluble myelin basic protein. J. Neuroimmunol. 2006, 177, 27-39. [CrossRef]

122. Dziembowska, M.; Tham, T.; Lau, P.; Vitry, S.; Lazarini, F.; Dubois-Dalcq, M. A role for CXCR4 signaling in survival and migration of neural and oligodendrocyte precursors. Glia 2005, 50, 258-269. [CrossRef] [PubMed]

123. Williams, A.; Piaton, G.; Aigrot, M.-S.; Belhadi, A.; Théaudin, M.; Petermann, F.; Thomas, J.-L.; Zalc, B.; Lubetzki, C. Semaphorin 3A and 3F: Key players in myelin repair in multiple sclerosis? Brain 2007, 130, 2554-2565. [CrossRef]

124. Arnett, H.A.; Mason, J.T.; Marino, M.W.; Suzuki, K.; Matsushima, G.K.; Ting, J.P.-Y. TNF $\alpha$ promotes proliferation of oligodendrocyte progenitors and remyelination. Nat. Neurosci. 2001, 4, 1116-1122. [CrossRef] [PubMed]

125. Laflamme, N.; Cisbani, G.; Préfontaine, P.; Srour, Y.; Bernier, J.; St-Pierre, M.-K.; Tremblay, M.-È.; Rivest, S. mCSF-Induced Microglial Activation Prevents Myelin Loss and Promotes Its Repair in a Mouse Model of Multiple Sclerosis. Front. Cell. Neurosci. 2018, 12, 178. [CrossRef] [PubMed]

126. Guerrero, B.L.; Sicotte, N.L. Microglia in Multiple Sclerosis: Friend or Foe? Front. Immunol. 2020, 11, 374. [CrossRef] [PubMed]

127. Yang, Q.; Zheng, C.; Cao, J.; Cao, G.; Shou, P.; Lin, L.; Velletri, T.; Jiang, M.; Chen, Q.; Han, Y.; et al. Spermidine alleviates experimental autoimmune encephalomyelitis through inducing inhibitory macrophages. Cell Death Differ. 2016, 23, $1850-1861$. [CrossRef]

128. Xu, L.; Hilliard, B.; Carmody, R.J.; Tsabary, G.; Shin, H.; Christianson, D.W.; Chen, Y.H. Arginase and autoimmune inflammation in the central nervous system. Immunology 2003, 110, 141-148. [CrossRef]

129. Miron, V.E.; Franklin, R. Macrophages and CNS remyelination. J. Neurochem. 2014, 130, 165-171. [CrossRef]

130. Locatelli, G.; Theodorou, D.; Kendirli, A.; Jordão, M.J.C.; Staszewski, O.; Phulphagar, K.; Cantuti-Castelvetri, L.; Dagkalis, A.; Bessis, A.; Simons, M.; et al. Mononuclear phagocytes locally specify and adapt their phenotype in a multiple sclerosis model. Nat. Neurosci. 2018, 21, 1196-1208. [CrossRef] 
131. Wolswijk, G. Oligodendrocyte precursor cells in the demyelinated multiple sclerosis spinal cord. Brain 2002, 125, 338-349. [CrossRef]

132. Patani, R.; Balaratnam, M.; Vora, A.; Reynolds, R. Remyelination can be extensive in multiple sclerosis despite a long disease course. Neuropathol. Appl. Neurobiol. 2007, 33, 277-287. [CrossRef]

133. Pang, Y.; Zheng, B.; Fan, L.-W.; Rhodes, P.G.; Cai, Z. IGF-1 protects oligodendrocyte progenitors against TNF $\alpha$-induced damage by activation of PI3K/Akt and interruption of the mitochondrial apoptotic pathway. Glia 2007, 55, 1099-1107. [CrossRef] [PubMed]

134. Cannella, B.; Pitt, D.; Capello, E.; Raine, C.S. Insulin-Like Growth Factor-1 Fails to Enhance Central Nervous System Myelin Repair during Autoimmune Demyelination. Am. J. Pathol. 2000, 157, 933-943. [CrossRef]

135. Zhang, J.; Kramer, E.G.; Mahase, S.; Dutta, D.; Bonnamain, V.; Argaw, A.T.; John, G.R. Targeting Oligodendrocyte Protection and Remyelination in Multiple Sclerosis. Mt. Sinai J. Med. J. Transl. Pers. Med. 2011, 78, 244-257. [CrossRef] [PubMed]

136. Var, S.R.; Byrd-Jacobs, C.A. Role of Macrophages and Microglia in Zebrafish Regeneration. Int. J. Mol. Sci. 2020, $21,4768$. [CrossRef]

137. Kerschensteiner, M.; Gallmeier, E.; Behrens, L.; Leal, V.V.; Misgeld, T.; Klinkert, W.E.F.; Kolbeck, R.; Hoppe, E.; Oropeza-Wekerle, R.-L.; Bartke, I.; et al. Activated Human T Cells, B Cells, and Monocytes Produce Brain-derived Neurotrophic Factor In Vitro and in Inflammatory Brain Lesions: A Neuroprotective Role of Inflammation? J. Exp. Med. 1999, 189, 865-870. [CrossRef]

138. Stadelmann, C.; Kerschensteiner, M.; Misgeld, T.; Brück, W.; Hohlfeld, R.; Lassmann, H. BDNF and gp145trkB in multiple sclerosis brain lesions: Neuroprotective interactions between immune and neuronal cells? Brain 2002, 125, 75-85. [CrossRef]

139. Huang, E.J.; Reichardt, L.F. Neurotrophins: Roles in Neuronal Development and Function. Annu. Rev. Neurosci. 2001, 24, 677-736. [CrossRef]

140. Vondran, M.W.; Singh, H.; Honeywell, J.Z.; Dreyfus, C.F. Levels of BDNF Impact Oligodendrocyte Lineage Cells following a Cuprizone Lesion. J. Neurosci. 2011, 31, 14182-14190. [CrossRef]

141. Fletcher, J.L.; Wood, R.J.; Nguyen, J.; Norman, E.M.; Jun, C.M.; Prawdiuk, A.R.; Biemond, M.; Nguyen, H.T.; Northfield, S.; Hughes, R.A.; et al. Targeting TrkB with a Brain-Derived Neurotrophic Factor Mimetic Promotes Myelin Repair in the Brain. J. Neurosci. 2018, 38, 7088-7099. [CrossRef] [PubMed]

142. Rahimlou, M.; Hosseini, S.A.; Majdinasab, N.; Haghighizadeh, M.H.; Husain, D. Effects of long-term administration of MultiStrain Probiotic on circulating levels of BDNF, NGF, IL-6 and mental health in patients with multiple sclerosis: A randomized, double-blind, placebo-controlled trial. Nutr. Neurosci. 2020, 2020, 1-12. [CrossRef] [PubMed]

143. Platten, M.; Steinman, L. Multiple sclerosis: Trapped in deadly glue. Nat. Med. 2005, 11, 252-253. [CrossRef] [PubMed]

144. Takeuchi, H.; Wang, J.; Kawanokuchi, J.; Mitsuma, N.; Mizuno, T.; Suzumura, A. Interferon- $\gamma$ induces microglial-activationinduced cell death: A hypothetical mechanism of relapse and remission in multiple sclerosis. Neurobiol. Dis. 2006, 22, 33-39. [CrossRef] [PubMed]

145. Heppner, F.; Greter, M.; Marino, D.; Falsig, J.; Raivich, G.; Hövelmeyer, N.; Waisman, A.; Rülicke, T.; Prinz, M.; Priller, J.; et al. Experimental autoimmune encephalomyelitis repressed by microglial paralysis. Nat. Med. 2005, 11, 146-152. [CrossRef] [PubMed]

146. Ponomarev, E.; Shriver, L.P.; Dittel, B.N. CD40 Expression by Microglial Cells Is Required for Their Completion of a Two-Step Activation Process during Central Nervous System Autoimmune Inflammation. J. Immunol. 2006, 176, 1402-1410. [CrossRef]

147. Klinkert, W.; Kojima, K.; Lesslauer, W.; Rinner, W.; Lassmann, H.; Wekerle, H. TNF- $\alpha$ receptor fusion protein prevents experimental auto-immune encephalomyelitis and demyelination in Lewis rats: An overview. J. Neuroimmunol. 1997, 72, 163-168. [CrossRef]

148. Goldmann, T.; Wieghofer, P.; Müller, P.-F.; Wolf, Y.; Varol, D.; Yona, S.; Brendecke, S.M.; Kierdorf, K.; Staszewski, O.; Datta, M.; et al. A new type of microglia gene targeting shows TAK1 to be pivotal in CNS autoimmune inflammation. Nat. Neurosci. 2013, 16, 1618-1626. [CrossRef]

149. Pang, Y.; Campbell, L.; Zheng, B.; Fan, L.; Cai, Z.; Rhodes, P. Lipopolysaccharide-activated microglia induce death of oligodendrocyte progenitor cells and impede their development. Neuroscience 2010, 166, 464-475. [CrossRef]

150. Li, J.; Ramenaden, E.R.; Peng, J.; Koito, H.; Volpe, J.J.; Rosenberg, P.A. Tumor Necrosis Factor Mediates LipopolysaccharideInduced Microglial Toxicity to Developing Oligodendrocytes When Astrocytes Are Present. J. Neurosci. 2008, 28, 5321-5330. [CrossRef]

151. Yeo, Y.A.; Gómez, J.M.M.; Croxford, J.L.; Gasser, S.; Ling, E.-A.; Schwarz, H. CD137 ligand activated microglia induces oligodendrocyte apoptosis via reactive oxygen species. J. Neuroinflamm. 2012, 9, 173. [CrossRef]

152. Brambilla, R. The contribution of astrocytes to the neuroinflammatory response in multiple sclerosis and experimental autoimmune encephalomyelitis. Acta Neuropathol. 2019, 137, 757-783. [CrossRef]

153. Colombo, E.; Farina, C. Astrocytes: Key Regulators of Neuroinflammation. Trends Immunol. 2016, 37, 608-620. [CrossRef]

154. Liddelow, S.A.; Guttenplan, K.A.; Clarke, L.E.; Bennett, F.C.; Bohlen, C.J.; Schirmer, L.; Bennett, M.L.; Münch, A.E.; Chung, W.-S.; Peterson, T.C.; et al. Neurotoxic reactive astrocytes are induced by activated microglia. Nature 2017, 541, 481-487. [CrossRef]

155. Brambilla, R. Neuroinflammation, the thread connecting neurological disease. Acta Neuropathol. 2019, 137, 689-691. [CrossRef]

156. Tsouki, F.; Williams, A. Multifaceted involvement of microglia in gray matter pathology in multiple sclerosis. Stem Cells 2021. [CrossRef]

157. Dalton, C.M.; Chard, D.; Davies, G.R.; Miszkiel, K.A.; Altmann, D.R.; Fernando, K.; Plant, G.T.; Thompson, A.; Miller, D.H. Early development of multiple sclerosis is associated with progressive grey matter atrophy in patients presenting with clinically isolated syndromes. Brain 2004, 127, 1101-1107. [CrossRef] 
158. Salter, M.W.; Stevens, B. Microglia emerge as central players in brain disease. Nat. Med. 2017, 23, 1018-1027. [CrossRef]

159. Albert, M.; Antel, J.; Brück, W.; Stadelmann, C. Extensive Cortical Remyelination in Patients with Chronic Multiple Sclerosis. Brain Pathol. 2007, 17, 129-138. [CrossRef]

160. Strijbis, E.M.; Kooi, E.-J.; Van Der Valk, P.; Geurts, J.J. Cortical Remyelination Is Heterogeneous in Multiple Sclerosis. J. Neuropathol. Exp. Neurol. 2017, 76, 390-401. [CrossRef]

161. Van Der Poel, M.; Ulas, T.; Mizee, M.R.; Hsiao, C.-C.; Miedema, S.; Adelia; Schuurman, K.G.; Helder, B.; Tas, S.W.; Schultze, J.L.; et al. Transcriptional profiling of human microglia reveals grey-white matter heterogeneity and multiple sclerosis-associated changes. Nat. Commun. 2019, 10, 1139. [CrossRef]

162. Zoupi, L.; Booker, S.A.; Eigel, D.; Werner, C.; Kind, P.C.; Spires-Jones, T.L.; Newland, B.; Williams, A.C. Selective vulnerability of inhibitory networks in multiple sclerosis. Acta Neuropathol. 2021, 141, 415-429. [CrossRef]

163. Di Filippo, M.; de Iure, A.; Giampà, C.; Chiasserini, D.; Tozzi, A.; Orvietani, P.L.; Ghiglieri, V.; Tantucci, M.; Durante, V.; Quiroga-Varela, A.; et al. Persistent activation of microglia and NADPH oxidase drive hippocampal dysfunction in experimental multiple sclerosis. Sci. Rep. 2016, 6, 20926. [CrossRef] [PubMed]

164. Nisticò, R.; Mango, D.; Mandolesi, G.; Piccinin, S.; Berretta, N.; Pignatelli, M.; Feligioni, M.; Musella, A.; Gentile, A.; Mori, F.; et al. Inflammation Subverts Hippocampal Synaptic Plasticity in Experimental Multiple Sclerosis. PLoS ONE 2013, 8, e54666. [CrossRef]

165. Jafari, M.; Schumacher, A.-M.; Snaidero, N.; Gavilanes, E.M.U.; Neziraj, T.; Kocsis-Jutka, V.; Engels, D.; Jürgens, T.; Wagner, I.; Weidinger, J.D.F.; et al. Phagocyte-mediated synapse removal in cortical neuroinflammation is promoted by local calcium accumulation. Nat. Neurosci. 2021, 24, 355-367. [CrossRef]

166. Miyamoto, A.; Wake, H.; Ishikawa, A.W.; Eto, K.; Shibata, K.; Murakoshi, H.W.H.; Koizumi, K.S.S.; Moorhouse, A.; Yoshimura, A.W.I.Y.; Nabekura, J. Microglia contact induces synapse formation in developing somatosensory cortex. Nat. Commun. 2016, 7, 12540. [CrossRef]

167. Nguyen, P.T.; Dorman, L.C.; Pan, S.; Vainchtein, I.D.; Han, R.T.; Nakao-Inoue, H.; Taloma, S.E.; Barron, J.J.; Molofsky, A.B.; Kheirbek, M.A.; et al. Microglial Remodeling of the Extracellular Matrix Promotes Synapse Plasticity. Cell 2020, 182, 388-403.e15. [CrossRef]

168. Herranz, E.; Giannì, C.; Louapre, C.; Treaba, C.A.; Govindarajan, S.T.; Ouellette, R.; Loggia, M.L.; Sloane, J.; Madigan, N.; Izquierdo-Garcia, D.; et al. Neuroinflammatory component of gray matter pathology in multiple sclerosis. Ann. Neurol. 2016, 80, 776-790. [CrossRef]

169. Schirmer, L.; Velmeshev, D.; Holmqvist, S.; Kaufmann, M.; Werneburg, S.; Jung, D.; Vistnes, S.; Stockley, J.H.; Young, A.; Steindel, M.; et al. Neuronal vulnerability and multilineage diversity in multiple sclerosis. Nat. Cell Biol. 2019, 573, 75-82. [CrossRef]

170. Masuda, T.; Sankowski, R.; Staszewski, O.; Böttcher, C.; Amann, L.; Sagar; Scheiwe, C.; Nessler, S.; Kunz, P.; Van Loo, G.; et al. Spatial and temporal heterogeneity of mouse and human microglia at single-cell resolution. Nature 2019, 566, 388-392. [CrossRef]

171. Werneburg, S.; Jung, J.; Kunjamma, R.B.; Ha, S.-K.; Luciano, N.J.; Willis, C.; Gao, G.; Biscola, N.P.; Havton, L.; Crocker, S.J.; et al Targeted Complement Inhibition at Synapses Prevents Microglial Synaptic Engulfment and Synapse Loss in Demyelinating Disease. Immunology 2020, 52, 167-182.e7. [CrossRef]

172. Molina-Gonzalez, I.; Miron, V.E. Astrocytes in myelination and remyelination. Neurosci. Lett. 2019, 713, 134532. [CrossRef] [PubMed]

173. Kato, G.; Inada, H.; Wake, H.; Akiyoshi, R.; Miyamoto, A.; Eto, K.; Ishikawa, T.; Moorhouse, A.J.; Strassman, A.M.; Nabekura, J. Microglial Contact Prevents Excess Depolarization and Rescues Neurons from Excitotoxicity. eNeuro 2016, 3. [CrossRef] [PubMed]

174. Cserép, C.; Pósfai, B.; Lénárt, N.; Fekete, R.; László, Z.I.; Lele, Z.; Orsolits, B.; Molnár, G.; Heindl, S.; Schwarcz, A.D.; et al. Microglia monitor and protect neuronal function through specialized somatic purinergic junctions. Science 2020, 367, 528-537. [CrossRef] [PubMed]

175. Kaiser, T.; Feng, G. Tmem119-EGFP and Tmem119-CreERT2 Transgenic Mice for Labeling and Manipulating Microglia. eNeuro 2019, 6. [CrossRef] [PubMed]

176. Masuda, T.; Amann, L.; Sankowski, R.; Staszewski, O.; Lenz, M.; D’Errico, P.; Snaidero, N.; Jordão, M.J.C.; Böttcher, C.; Kierdorf, K.; et al. Novel Hexb-based tools for studying microglia in the CNS. Nat. Immunol. 2020, 21, 802-815. [CrossRef]

177. Li, Q.; Cheng, Z.; Zhou, L.; Darmanis, S.; Neff, N.F.; Okamoto, J.; Gulati, G.; Bennett, M.; Sun, L.O.; Clarke, L.E.; et al. Developmental Heterogeneity of Microglia and Brain Myeloid Cells Revealed by Deep Single-Cell RNA Sequencing. Neuron 2019, 101, 207-223.e10. [CrossRef]

178. Geirsdottir, L.; David, E.; Keren-Shaul, H.; Weiner, A.; Bohlen, S.C.; Neuber, J.; Balic, A.; Giladi, A.; Sheban, F.; Dutertre, C.-A.; et al. Cross-Species Single-Cell Analysis Reveals Divergence of the Primate Microglia Program. Cell 2019, 179, 1609-1622.e16. [CrossRef]

179. Muffat, J.; Li, Y.; Yuan, B.; Mitalipova, M.; Omer, A.; Corcoran, S.; Bakiasi, G.; Tsai, L.-H.; Aubourg, P.; Ransohoff, R.M.; et al. Efficient derivation of microglia-like cells from human pluripotent stem cells. Nat. Med. 2016, 22, 1358-1367. [CrossRef]

180. Pandya, H.; Shen, M.J.; Ichikawa, D.M.; Sedlock, A.B.; Choi, Y.; Johnson, K.R.; Kim, G.; Brown, M.; Elkhaloun, A.G.; Maric, D.; et al. Differentiation of human and murine induced pluripotent stem cells to microglia-like cells. Nat. Neurosci. 2017, $20,753-759$. [CrossRef]

181. Abud, E.M.; Ramirez, R.N.; Martinez, E.S.; Healy, L.M.; Nguyen, C.H.H.; Newman, S.A.; Yeromin, A.V.; Scarfone, V.M.; Marsh, S.E.; Fimbres, C.; et al. iPSC-Derived Human Microglia-like Cells to Study Neurological Diseases. Neuron 2017, 94, 278-293.e9. [CrossRef] 
182. Quigley, E.M.M. Microbiota-Brain-Gut Axis and Neurodegenerative Diseases. Curr. Neurol. Neurosci. Rep. 2017, 17, 94. [CrossRef]

183. Chen, J.; Chia, N.; Kalari, K.; Yao, J.Z.; Novotna, M.; Soldan, M.M.P.; Luckey, D.H.; Marietta, E.V.; Jeraldo, P.; Chen, X.; et al. Multiple sclerosis patients have a distinct gut microbiota compared to healthy controls. Sci. Rep. 2016, 6, 28484. [CrossRef]

184. Cantarel, B.L.; Waubant, E.; Chehoud, C.; Kuczynski, J.; DeSantis, T.Z.; Warrington, J.; Venkatesan, A.; Fraser, C.M.; Mowry, E.M. Gut Microbiota in Multiple Sclerosis. J. Investig. Med. 2015, 63, 729-734. [CrossRef] [PubMed]

185. Cosorich, I.; Costa, G.D.; Sorini, C.; Ferrarese, R.; Messina, M.J.; Dolpady, J.; Radice, E.; Mariani, A.; Testoni, P.A.; Canducci, F.; et al. High frequency of intestinal T H 17 cells correlates with microbiota alterations and disease activity in multiple sclerosis. Sci. Adv. 2017, 3, e1700492. [CrossRef] [PubMed]

186. Cekanaviciute, E.; Yoo, B.B.; Runia, T.F.; Debelius, J.W.; Singh, S.; Nelson, C.; Kanner, R.; Bencosme, Y.; Lee, Y.K.; Hauser, S.L.; et al. Gut bacteria from multiple sclerosis patients modulate human T cells and exacerbate symptoms in mouse models. Proc. Natl. Acad. Sci. USA 2017, 114, 10713-10718. [CrossRef] [PubMed]

187. Jangi, S.; Gandhi, R.; Cox, L.; Li, N.; Von Glehn, F.; Yan, R.; Patel, B.; Mazzola, M.A.; Liu, S.; Glanz, B.L.; et al. Alterations of the human gut microbiome in multiple sclerosis. Nat. Commun. 2016, 7, 12015. [CrossRef]

188. Berer, K.; Gerdes, L.A.; Cekanaviciute, E.; Jia, X.; Xiao, L.; Xia, Z.; Liu, C.; Klotz, L.; Stauffer, U.; Baranzini, S.; et al. Gut microbiota from multiple sclerosis patients enables spontaneous autoimmune encephalomyelitis in mice. Proc. Natl. Acad. Sci. USA 2017, 114, 10719-10724. [CrossRef]

189. Wekerle, H.; Berer, K.; Krishnamoorthy, G. Remote control—triggering of brain autoimmune disease in the gut. Curr. Opin. Immunol. 2013, 25, 683-689. [CrossRef] [PubMed]

190. Chen, Z.; Zhong, D.; Li, G. The role of microglia in viral encephalitis: A review. J. Neuroinflammation 2019, 16, 1-12. [CrossRef]

191. Lu, J.; Lu, L.; Yu, Y.; Baranowski, J.; Claud, E.C. Maternal administration of probiotics promotes brain development and protects offspring's brain from postnatal inflammatory insults in C57/BL6J mice. Sci. Rep. 2020, 10, 8178. [CrossRef]

192. McMurran, C.E.; de la Fuente, A.G.; Penalva, R.; Ben Menachem-Zidon, O.; Dombrowski, Y.; Falconer, J.; Gonzalez, G.A.; Zhao, C.; Krause, F.N.; Young, A.M.H.; et al. The microbiota regulates murine inflammatory responses to toxin-induced CNS demyelination but has minimal impact on remyelination. Proc. Natl. Acad. Sci. USA 2019, 116, 25311-25321. [CrossRef] [PubMed]

193. Domingues, H.; Portugal, C.; Socodato, R.; Relvas, J.B. Oligodendrocyte, Astrocyte, and Microglia Crosstalk in Myelin Development, Damage, and Repair. Front. Cell Dev. Biol. 2016, 4, 71. [CrossRef] [PubMed] 